10 years ESJ

Special edition

\title{
SEIMR/R-S. General Epidemic Simulation Model Multi-Infected States - Multi Sociodemographic Segments - Multi-Region Mobility. Theory
}

\author{
Jesus Velasquez-Bermudez, Ph.D. \\ Chief Scientific Officer, RCADT Inc. \\ Research Center for Advanced Decision Technologies, FL, USA
}

Doi: 10.19044/esj.2021.v17n31p195

Submitted: 01 May 2021

Accepted: 06 September 2021

Published: 15 September 2021
Copyright 2021 Author(s)

Under Creative Commons BY-NC-ND

4.0 OPEN ACCESS

Academic Editors: Georgios Farantos \& Nikitas-Spiros Koutsoukis

Cite As:

Velasquez-Bermudez J. (2021). SEIMR/R-S. General Epidemic Simulation Model MultiInfected States - Multi Sociodemographic Segments - Multi-Region Mobility. Theory. European Scientific Journal, ESJ, 17 (31), 195.

https://doi.org/10.19044/esj.2021.v17n31p195

\section{Abstract}

SEIMR/R-S corresponds to a generalized mathematical model of pandemics that enhances traditional, aggregated simulation models when considering inter-regional impacts in a macro region (conurbed); SEIMR/R-S also considers the impact of modeling the population divided into sociodemographic segments based on age and economic stratum (it is possible to include other dimensions, for example: ethnics, gender, ... ). SEIMR/R-S is the core of the SEIMR/R-S/OPT epidemic management optimization model that determines optimal policies (mitigation and confinement) considering the spatial distribution of the population, segmented sociodemographically and multiple type of vaccines. The formulation of SEIMR/R-S/OPT is presented by Velasquez-Bermudez (2021a) that includes the modeling of the vaccination process. SEIMR/R-S can be understood and used by any epidemiologist, and/or physician, working with SIR, SEIR or similar simulation models, and by professionals working on the issue of public policies for epidemic control. Following the theory presented in this document, ITCM (Instituto Tecnologico de Ciudad Madero, México) implemented the SEIMR/R-S epidemic model in a JAVA program (Velasquez-Bermudez et. al, 2021). This program may be 
used by the organizations that considers the SEIMR/R-S will be useful for management the COVID-19 pandemic, it is presented by VelasquezBermudez et al. (2021).

Keywords: Pandemic Management, Epidemic Mathematics, Optimization, Health Decision Support Systems

\section{1. $\quad$ Epidemic \& Control Policies Model}

The SEIMR/R-S is a detailed epidemic model that is the result of integrating the SIR, SEIR and SEI3RD model; in these standard models the population is grouped in only one homogenous group. SEIMR/R-S extends the modeling to a multi-sociodemographic-segment multi-region system.

SEIMR/R-S model describes the epidemic with following states:

S Susceptible: initially covers all population that potentially can be infected (SU)

E Exposed: Population that has been infected and are in an incubation (latency) period (EX). The model SIR does not include this state.

IM Multi-Infected: Population that has been infected and has active the pathogen in different states of development (I0, I1,I2, .. , IN). The active infected states are ordered according to the severity of the infection. The modeled SIR and SEIR consider only one infected state. For convenience, the last state is called "IN"

$\mathrm{R} \quad$ Recovered: Recovering population (RE)

$\mathrm{R}-\mathrm{S}$ is related with the Region-Segment model that considers multiples regions where live people classified in multiples sociodemographic segments.

\subsection{Conceptual Framewor}

The goal of epidemic control strategies is to reduce the basic reproduction number $\mathrm{R}_{0}$. This can be achieved by reducing susceptibility or contact rates in the population or the infectiousness of infected populations. The potential effectiveness of medical intervention by varying the infectiousness of infected populations and nonmedical interventions by reducing the contact rates in the population have been examined. In medical intervention, use of vaccines and/or antiviral agents for case of treatment can increase the recovery rate and reduce the death rate. On the other hand, in nonmedical interventions, reducing population contact rates through social distancing and travel restrictions can reduce the impact on the transmission 


\section{Figure 1. GOALOFEPIDEMICMODELING}

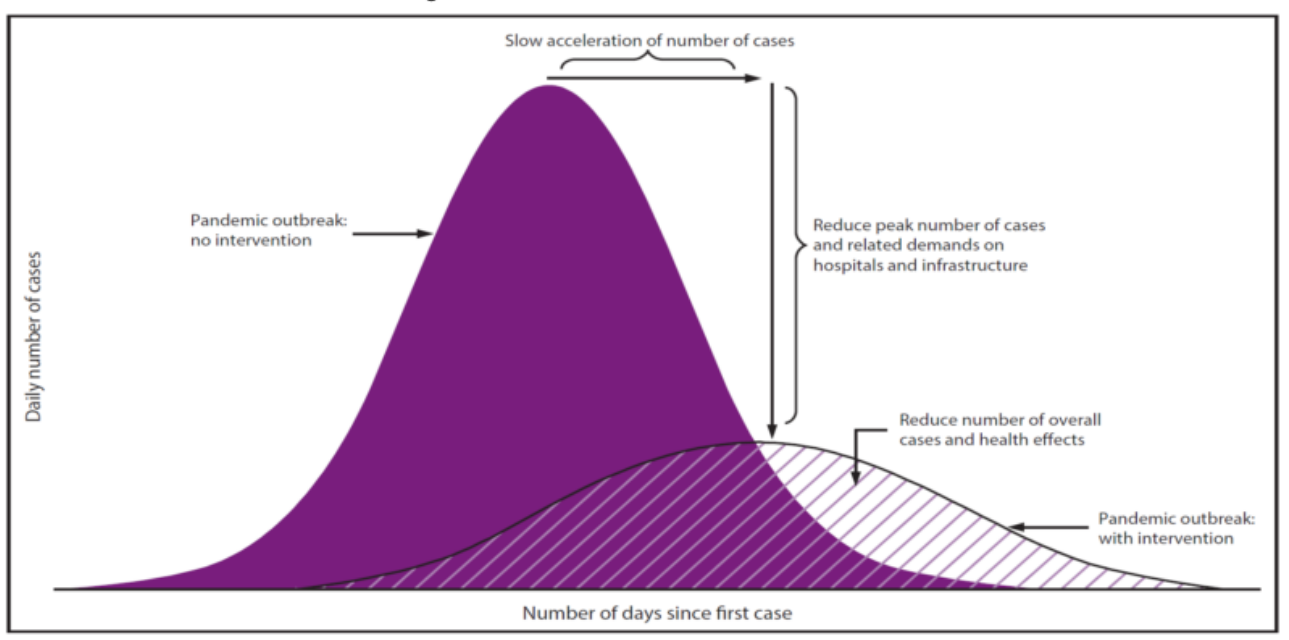

Source: Adapted from: $C D C$. Interim pre-pandemic planning guidance: community strategy for pandemic influenza mitigation in the United States-early, targeted, layered use of nonpharmaceutical interventions. Atlanta, GA: US Department of Health and Human Services, CDC; 2007. https://stacks.cdc.gov/view/cdc/11425.

Control of an outbreak relies partly on identification of the disease parameters that lead to a significant reduction $\mathrm{R}_{0}$ that may be function of several parameters of which $\gamma$, the recovery rate for clinically ill and $b$, the transmission coefficient, are the most sensitive parameters. These two parameters can be controlled by medical intervention and nonmedical interventions.

The modeling of epidemics in a solidly developed area of scientific knowledge, widely studied based on simulation models. The table of epidemic models shows some of the best-known models

The following documents have been consulted, referenced and/or used for writing the following numerals:

- Brauer, F. and Castillo-Chavez, C. (2000). Mathematical Models in Population Biology and Epidemiology. Springer, New York, 2000.

- Cai, Y., Kang, Y., Banerjee, M., \& Wang, W. (2015). A stochastic SIRS epidemic model with infectious force under intervention strategies. Journal of Differential Equations, 259(12), 7463-7502.

- Carcione, J., Santos J. E., Bagaini, C. and Jing, Ba. (2020) A Simulation of a COVID-19 Epidemic Based on a Deterministic SEIR Model.

- Erdem, M., Safan, M., \& Castillo-Chavez, C. (2017). Mathematical analysis of an SIQR influenza model with imperfect quarantine. Bulletin of mathematical biology, 79(7), 1612-1636.

- Eubank, S., Eckstrand, I., Lewis, B., Venkatramanan, S., Marathe, M., \& Barrett, C. L. (2020). Commentary on Ferguson, et al.,"Impact of Non-pharmaceutical Interventions (NPIs) to Reduce COVID-19 
Mortality and Healthcare Demand". Bulletin of Mathematical Biology, 82, 1-7.

- Ferguson, N., Laydon, D., Nedjati Gilani, G., Imai, N., Ainslie, K., Baguelin, M., ... \& Dighe, A. (2020). Report 9: Impact of nonpharmaceutical interventions (NPIs) to reduce COVID19 mortality and healthcare demand.

- Hethcote, H. W. (2000). "The Mathematics of Infectious Diseases." SIAM Review 42.4 (2000), pp. 599-653.

- Huang G. (2016). Artificial infectious disease optimization: A SEIQR epidemic dynamic model-based function optimization algorithm. Swarm and evolutionary computation, 27, 31-67. https://doi.org/10.1016/j.swevo.2015.09.007

- Jing, W., Jin, Z., \& Zhang, J. (2018). An SIR pairwise epidemic model with infection age and demography. Journal of biological dynamics, 12(1), 486-508.

- Kermack, W.O. and Mc Kendrick, A. G.,(1927) "Contributions to the Mathematical Theory of Epidemics, Part I". Proc. R. Soc. London, Ser. A, 115, 1927, 700-721.

- Liu M. and Liang, J. (2013). Dynamic optimization model for allocating medical resources in epidemic controlling. Journal of Industrial Engineering and Management JIEM, 2013 - 6(1):73-88 Online ISSN: 2013-0953

- Massad, E., Bruattini, N.M., Coutinho, B. A. F. and Lopez, F. L., (2007). "The 1918 Influenza An Epidemic in the City" of Sao Paulo", Brazil, Medical Hypotheses, 68, 2007, 442-445

- Mejía Becerra, J. D. et. al. (2020). "Modelación Matemática de la Propagación del SARS-CoV-2 en la Ciudad de Bogotá. Documento de Circulación Informal

- Pang, W. (2020). Public Health Policy: COVID-19 Epidemic and SEIR Model with Asymptomatic Viral Carriers. Department of Mathematics and Statistics, McMaster University arXiv:2004.06311v1 [q-bio.PE] 14 Apr 2020.

- Radulescu, A., \& Cavanagh, K. (2020). Management strategies in a SEIR model of COVID 19 community spread. arXiv preprint arXiv:2003.11150.

- Samsuzzoha, Md. (2012) . "A Study on Numerical Solutions of Epidemic Models". Doctoral Thesis, Swinburne University of Technology, Australia, 2012. 


\begin{tabular}{|c|c|c|}
\hline \multicolumn{3}{|c|}{ Table 1. Traditional Epidemic Models } \\
\hline Model & Description & Reference \\
\hline SIR & $\begin{array}{l}\text { Susceptibility (S), Infection (I) and Recovery } \\
\text { (R) }\end{array}$ & $\begin{array}{c}\text { Kermack \& Mc Kendrick } \\
\text { (1927) Jing (2018) }\end{array}$ \\
\hline SEIR & $\begin{array}{l}\text { Susceptibility (S), Exposure (E), Infection (I) } \\
\text { and Recovery (R) }\end{array}$ & Hethcote $(2000)$ \\
\hline SEI3RD & $\begin{array}{l}\text { Susceptibility (S), Exposure (E), 3+1 Infection } \\
\text { States (I3), Recovery (R) and Death (D) }\end{array}$ & $\begin{array}{l}\text { Mejía Becerra et. al. } \\
(2020)\end{array}$ \\
\hline SEIQR & $\begin{array}{l}\text { Susceptibility (S), Exposure (E), Infection (I), } \\
\text { Quarantine (Q) and Recovery (R) }\end{array}$ & Huang (2016) \\
\hline SIRS & $\begin{array}{l}\text { Susceptibility (S), Infection (I), Recovery (R) } \\
\text { and Susceptibility (S) }\end{array}$ & Cai (2015) \\
\hline
\end{tabular}

Then, an epidemiological model is defined based on differential equations that explain the evolution of the process without human intervention. These differential equations can be established based on the population (number of people) who are in a certain "epidemic" state or based on the fraction of the population that is in that state. The epidemic models are nonlinear systems of ordinary differential equations, traditionally this equations system is solved using simulation models based in a discrete approximation for continuous derivatives, be it over time or space. There are many possible schemes. These models are used to analyze several widely discussed (predefined) scenarios and provide evidence on their effectiveness and are not oriented to get the optimal solution of a mix of control policies.

The added value by mathematical programming approach is to convert simulation models into optimization models to be able to combine them with other mathematical programming models, following the principles of structured mathematical modeling that allows join multiple problems of mathematical programming in a single model. Based on the above, the formulation of the models is done by means of algebraic equations that represent how the epidemiological process evolves during the planning horizon.

For the optimization epidemic modeling, the approach is based on multiple state chains that can be associated with semi-Markov chains; initially, it was proposed to model based on the approach of semi-Markovian processes (changing transition matrices over time) but such an approach brings multiple complications in the math formulation of probabilities.

After analyzing the implementation of main (most known) epidemiological models (SIR, SEIR), it was decided to directly model discrete versions of differential equations as they maintain direct connection with biological parameters, which facilitates the connection of these parameters with sociodemographic segments.

Therefore, all epidemiological models considered should be formulated in one of the following terms. 
- The time unit of the differential equations is one day.

- The states contain the fraction of the population in each state.

- The time of the optimization model may be divided in periods of multiple days (one week, seven days). In this case, the integration of the differential equations must be made using calculated parameters.

The epidemic states are showed in the next table. The models will be implemented using this nomenclature. The table includes the symbol used in the original models and the code used in this document.

\begin{tabular}{|c|c|c|c|}
\hline \multicolumn{4}{|c|}{ Table 2. Epidemic States } \\
\hline $\begin{array}{c}\text { Model } \\
\text { Symbol }\end{array}$ & $\begin{array}{l}\text { Epidemic } \\
\text { State }\end{array}$ & Description & Comments \\
\hline S & SU & $\begin{array}{l}\text { Susceptible } \\
\text { Population }\end{array}$ & $\begin{array}{l}\text { Those individuals who have not been exposed to the } \\
\text { pathogen and are susceptible to being infected by it. }\end{array}$ \\
\hline $\mathrm{E}$ & EX & $\begin{array}{l}\text { Exposed } \\
\text { Population }\end{array}$ & $\begin{array}{l}\text { Those individuals who are in the latency state; that } \\
\text { is, they have been inoculated by the pathogen but } \\
\text { are not yet infectious }\end{array}$ \\
\hline I & IN & $\begin{array}{l}\text { Infected } \\
\text { Population }\end{array}$ & $\begin{array}{l}\text { In SIR and SEIR models is infected population. It } \\
\text { must be the most critical state for infected people; } \\
\text { this is important for models that have more than one } \\
\text { epidemic states to describe the infection process. }\end{array}$ \\
\hline $\mathrm{I}_{0}$ & I0 & $\begin{array}{l}\text { Asymptomatic } \\
\text { Infectious }\end{array}$ & $\begin{array}{l}\text { Those individuals in the population who have been } \\
\text { inoculated by the virus are infectious but have not } \\
\text { developed symptoms. Those infected in this state } \\
\text { rarely learn that they have been infected. }\end{array}$ \\
\hline $\mathrm{I}_{1}$ & $\mathrm{I} 1$ & $\begin{array}{l}\text { Moderate } \\
\text { Symptoms } \\
\text { Infectious }\end{array}$ & $\begin{array}{l}\text { Those individuals in the population who are } \\
\text { infectious and have mild or moderate symptoms. } \\
\text { They are those who can be given management of the } \\
\text { disease at home. }\end{array}$ \\
\hline $\mathrm{I}_{2}$ & $\mathrm{I} 2$ & $\begin{array}{l}\text { Severe } \\
\text { Symptoms } \\
\text { Infectious }\end{array}$ & $\begin{array}{l}\text { Those individuals in the population who are } \\
\text { infectious and have severe but not critical } \\
\text { symptoms. Individuals present in this state require } \\
\text { hospitalization. }\end{array}$ \\
\hline $\mathrm{I}_{3}$ & IN & $\begin{array}{l}\text { Critical } \\
\text { Symptoms } \\
\text { Infectious }\end{array}$ & $\begin{array}{l}\text { It must be the most critical state for infected people; } \\
\text { this is important for models that have more than one } \\
\text { epidemic states to describe the infection process. In } \\
\text { SIR and SEIR models is infected population }\end{array}$ \\
\hline $\mathrm{R}$ & $\mathrm{RE}$ & $\begin{array}{l}\text { Recovered } \\
\text { Population }\end{array}$ & $\begin{array}{l}\text { Those individuals recover from infection, having } \\
\text { developed antibodies. In most of the models they } \\
\text { cannot be re-infected. }\end{array}$ \\
\hline & ED & Epidemic Dead & Individuals who fail the infection and die. \\
\hline & ND & Natural Dead & $\begin{array}{l}\text { Individuals who die by other reason different to the } \\
\text { epidemic }\end{array}$ \\
\hline & NP & New Population & $\begin{array}{l}\text { Individuals coming from an exogenous macro- } \\
\text { region. }\end{array}$ \\
\hline
\end{tabular}


The indexes used in the algebraic notation are presented in the next table, each index is associated to an entity of the information system.

\begin{tabular}{|c|c|c|}
\hline \multicolumn{3}{|c|}{ Table 3. Indexes } \\
\hline Index & Short Description & Long Description \\
\hline $\mathrm{ag}$ & Age & Age \\
\hline $\mathrm{mr}$ & Macro-region & Macro-Region \\
\hline $\mathrm{rg}, \mathrm{ro}, \mathrm{rd}$ & Region & Region (Basic Territory Unit) \\
\hline $\mathrm{ss}$ & Social Segment & Sociodemographic Segment \\
\hline st, s1 & Epidemic State & Epidemic State \\
\hline $\mathrm{t}, \mathrm{q}$ & Period & \\
\hline
\end{tabular}

The measurement units used are equal for all models

\begin{tabular}{|c|c|}
\hline \multicolumn{2}{|c|}{ Table 4. Measurement Unit } \\
\hline Measurement Unit & Description \\
\hline 1/peo-day & $1 /$ persons-day \\
\hline fpo/day & Fraction of population per day \\
\hline peo-day & Persons-day \\
\hline
\end{tabular}

One of the main limitations of the traditional approach is to assume that the entire population is homogeneous with respect to its epidemiological behavior. It is well known that the epidemic manifests differently in each sociodemographic segment and that the composition of sociodemographic segments depends on each region.

In order to enhance the model to be useful in real cases, it is assumed that there is a different pandemic (because it has different parameters) for each pair <region, sociodemographic-segment. These hypotheses may vary according to each case study. In this case, reference has been made to the data used to control the epidemic in a macro-region. It should be noted that the parameters of each epidemiological model vary in quantity but do not vary in the form of calculation.

The models are studied under the hypothesis of a homogeneous population in a region, then the epidemic is assumed to be particular to each duple $\langle$ rg,ss $\rangle$ and the equations are formulated depending on $\langle\mathrm{rg}$,ss $\rangle$. The advantage of this approach will be visualized when the epidemic model is coupled with the management of health resources and control policies, which can be individualized for each duple $\langle\mathrm{rg}$,ss $\rangle$.

The model parameters can be grouped by the original source of variation, these sources are:

- Pathogen: characteristics of the epidemic due to the pathogen

- Age: It is typical for recovery/worsening times (rates) and probability of recovery to be a function of age. 
- Economic stratum: influences the epidemic by means of the intensity of contact, product of the number, the duration, and the closeness of contact.

These parameters may also be a combined function of age and economic. In this document, the sociodemographic segments are a combination of age with an economic stratum. The biological parameters depend on age.

Additionally, may be considered people coming for the exogenous systems the macroregion, epidemic state NP.

\section{General Simulation Epidemic Model}

Below is presented an aggregate model of epidemic that is the result of integrating the SIR model, SEIR and SEI3RD; in these standard models the population is grouped in only one homogenous group. SEIMR/R-S extends the modeling to a multi-sociodemographic-segment multi-region system.

The general assumptions for standard epidemic models are:

- No vaccine exists

- The susceptible population is reduced through infection (moving to infective state).

- People who recovered after catch the virus will be insusceptible of it

- The population of infective class is increased by a fraction of susceptible individuals becoming infective.

- All other people are susceptible

- The population is homogenous

- The population of "critical" infective individuals is reduced by recovery from the disease.

SEIMR/R-S model describes the epidemic with following states:

$S$ Susceptible: initially covers all population that potentially can be infected (SU)

E Exposed: Population that has been infected and are in an incubation (latency) period (EX). The model SIR does not include this state.

IM Multi-Infected: Population that has been infected and has active the pathogen in different states of development (I0, I1,I2, .., IN). The active infected states are ordered according to the severity of the infection. The modeled SIR and SEIR consider only one infected state. For convenience, the last state is called "IN"

$\mathrm{R} \quad$ Recovered: Recovering population (RE)

$\mathrm{R}-\mathrm{S}$ is related with the Region-Segment model that considers multiples regions where live people classified in multiples sociodemographic segments. 
The next table shows the relation between models and epidemic states.

\begin{tabular}{|c|c|c|c|c|c|c|c|c|c|c|c|c|c|}
\hline \multicolumn{10}{|c|}{ Table 5. SEIMR/R-S Model Epidemic States } \\
\hline \multirow{3}{*}{ Model } & \multicolumn{10}{|c|}{ Model Epidemic States } \\
\cline { 2 - 17 } & \multicolumn{10}{|c|}{ Cxtended } & \multicolumn{1}{c|}{ Capacity } \\
\hline & $\mathrm{S}$ & $\mathrm{EX}$ & $\mathrm{I}_{0}$ & $\mathrm{I}_{1}$ & $\mathrm{I}_{2}$ & $\cdots$ & $\mathrm{I}_{\mathrm{N}}$ & $\mathrm{RE}$ & $\mathrm{NP}$ & $\mathrm{ED}$ & $\mathrm{ND}$ & $\mathrm{IU}$ & $\mathrm{CD}$ \\
& $\mathrm{U}$ & & & & & & & & & & & & \\
\hline SIR & $\mathrm{x}$ & & & & & & $\mathrm{x}$ & $\mathrm{x}$ & & & & & \\
\hline SEIR & $\mathrm{x}$ & $\mathrm{x}$ & & & & & $\mathrm{x}$ & $\mathrm{x}$ & & & & & \\
\hline SEI3RD & $\mathrm{x}$ & $\mathrm{x}$ & $\mathrm{x}$ & $\mathrm{x}$ & $\mathrm{x}$ & $\mathrm{x}$ & $\mathrm{x}$ & $\mathrm{x}$ & & $\mathrm{x}$ & & & \\
\hline SEIMR/R-S & $\mathrm{x}$ & $\mathrm{x}$ & $\mathrm{x}$ & $\mathrm{x}$ & $\mathrm{x}$ & $\mathrm{x}$ & $\mathrm{x}$ & $\mathrm{x}$ & $\mathrm{x}$ & $\mathrm{x}$ & $\mathrm{x}$ & $\mathrm{x}$ & $\mathrm{x}$ \\
\hline
\end{tabular}

\subsection{SIR: Epidemic Model}

The SIR model is a basic model in epidemic modeling (Kermack and Mc Kendrick, 1927). SIR process, starting with a susceptible host who becomes infected, the class of infection grow for the infected individuals to be able to transmit the infection to susceptible. When the infected individual is no longer able to transmit infection to susceptible individual, the infected individual is removed from the cycle of diseases transmission in the population. This model is based on the following assumption:

Then, the basic SIR model describes the epidemic with three states:

S Susceptible: initially covers all population that potentially can be infected (SU)

I Infected: Population that has been infected (IN)

$\mathrm{R}$ Recovered: Recovering population (RE)

The diagram shows the behavior of $S(t), I(t)$, and $R(t)$ when they are normalized using the initial population equal to 1 . The biological parameters used in SIR and SEIR model are described below.

\begin{tabular}{|c|c|c|c|}
\hline \multicolumn{4}{|c|}{ Table 6. SIR Model - Biological Parameters } \\
\hline Parameter & Description & Equation & $\begin{array}{c}\text { Measure } \\
\text { Unit }\end{array}$ \\
\hline $\mathrm{d}$ & Contact Intensity - Exogenous Parameter & & peo-day \\
\hline $\mathrm{w}$ & $\begin{array}{c}\text { Probability of transmission per contact } \\
\text { intensity (infectivity) }\end{array}$ & \\
\hline$\gamma$ & Recovery rate for clinically ill & & $\mathrm{fpo} / \mathrm{day}$ \\
\hline $\mathrm{m}$ & Epidemic death (mortality) rate & $\mathrm{fpo} / \mathrm{day}$ \\
\hline $\mathrm{m}^{\mathrm{N}}$ & Natural mortality rate & $\mathrm{fpo} / \mathrm{day}$ \\
\hline $\mathrm{k}$ & The latency period of the virus before \\
developing & & $\mathrm{day}$ \\
\hline $\mathrm{y}$ & Inverse virus latency period & $1 / \mathrm{k}$ & $1 / \mathrm{k}$ \\
\hline $\mathrm{b}$ & Inverse contact intensity $\times$ infectivity & $\mathrm{dd} \times \mathrm{w}$ & $\mathrm{dd} \times \mathrm{w}$ \\
\hline $\mathrm{r}$ & Relative removal rate & $\gamma / \mathrm{b}$ & \\
\hline $\mathrm{R}_{0}$ & Basic reproduction ratio/number & & \\
\hline
\end{tabular}


The diagram resumes the standard SIR epidemic model.
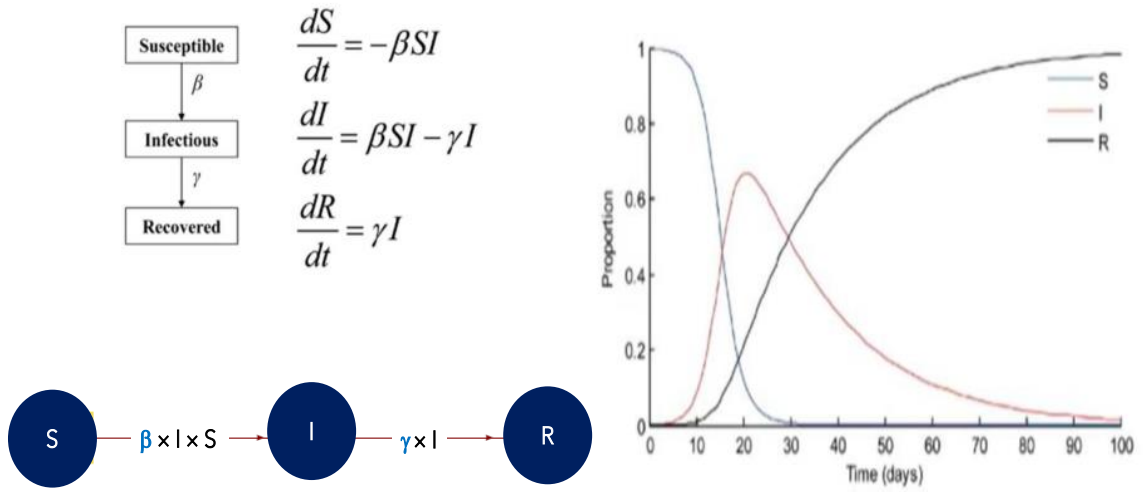

SIR model is represented based on three differential equations based on proportions of people in each state (the ratio between the people in a state with the initial population TPOB). The measurements between parentheses. $\partial \mathrm{S}(\mathrm{t}) / \partial \mathrm{t}(\mathrm{fpo} /$ day $)=-\beta(1 /$ fpo-day $) \times \mathrm{I}(\mathrm{t})(\mathrm{fpo}) \times \mathrm{S}(\mathrm{t})(\mathrm{fpo})$ $\partial \mathrm{I}(\mathrm{t}) / \partial \mathrm{t}($ fpo/day $)=\beta(1 /$ fpo-day $) \times \mathrm{I}(\mathrm{t})($ fpo $) \times \mathrm{S}(\mathrm{t})(\mathrm{fpo})-\gamma($ fpo/day $) \times \mathrm{I}(\mathrm{t})$ (fpo)

$\partial \mathrm{R}(\mathrm{t}) / \partial \mathrm{t}($ fpo/day $)=\gamma($ fpo/day $) \times \mathrm{I}(\mathrm{t})($ fpo $)$

where $S(t), I(t), R(t)$ represent the population of susceptible, infected, and recovered individuals, respectively. Adding these equations, the following condition must be hold

$$
\partial \mathrm{S}(\mathrm{t}) / \partial \mathrm{t}+\partial \mathrm{I}(\mathrm{t}) / \partial \mathrm{t}+\partial \mathrm{R}(\mathrm{t}) / \partial \mathrm{t}=0
$$

Additionally, SIR can be extended with other epidemic states for a more complete description of the system/epidemic:

NP New population entering the system, as people from abroad who in many cases are the ones who cause the epidemic (NP).

ED People who die due to the epidemic (these people die regardless of the management of the epidemic (D).

ND People who die from natural death $(\mathrm{N})$

ND and ED states should be included if it wants to account for the resources consumed by people who die, who are killed due the epidemic and due by causes other than the epidemic. 
For a more general formulation it is included the exogenous variable $\mathrm{NPX}(\mathrm{t})$ that represents the proportion of people arriving from an exogenous system, may be births or people arriving from a foreign country/region. The value of $\mathrm{NPX}(\mathrm{t})$ is a border condition with the foreign system over any value of $t$ it is calculated taking as reference the initial population TPOB. This adjustment may be important in regions with high people exchange rates, e.g., islands dedicated to tourism. Next table shows the parameters used to this modeling.

\begin{tabular}{|l|c|c|}
\hline \multicolumn{3}{|c|}{ Table 7. Exogenous System Parameters } \\
\hline Parameter & Description & Measure Unit \\
\hline $1^{\mathrm{E}}$ & Exposed rate coming from the exogenous system & fpo/day \\
\hline $1^{\mathrm{S}}$ & Susceptible rate coming from the exogenous system & fpo/day \\
\hline $1^{\mathrm{I}}$ & Infectious rate coming from the exogenous system & fpo/day \\
\hline $1^{\mathrm{R}}$ & Recovered rate coming from the exogenous system & fpo/day \\
\hline
\end{tabular}

Next diagram shows the epidemic system modeled.

Figure 3. STATE TRANSITION DIAGRAM - SIR MODEL

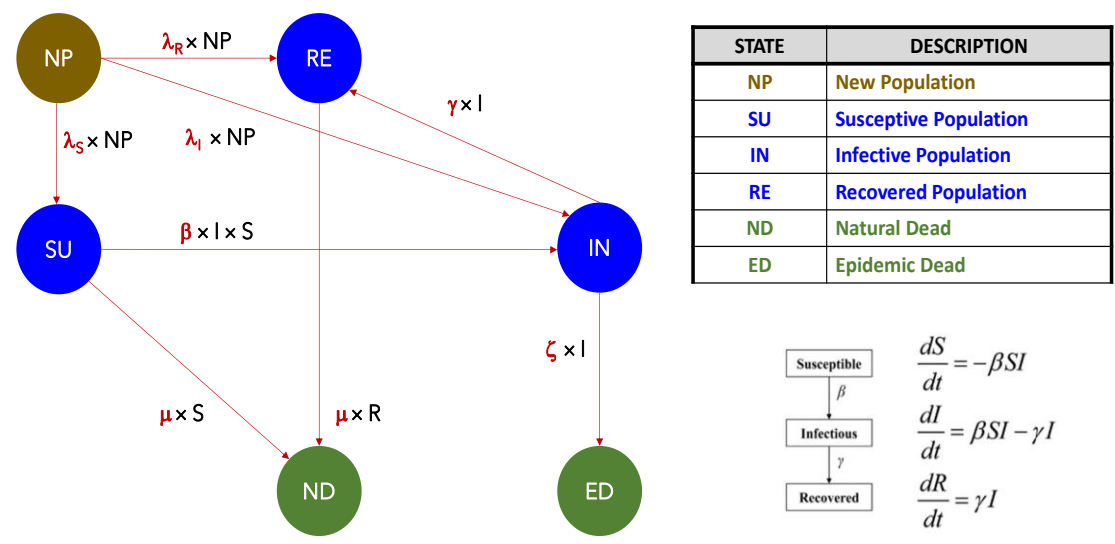

Then, the differential SIR equations must be adjusted:

$$
\begin{aligned}
& \partial \mathrm{S}(\mathrm{t}) / \partial \mathrm{t}=-\beta \times \mathrm{I}(\mathrm{t}) \times \mathrm{S}(\mathrm{t})+\lambda^{\mathrm{S}} \times \mathrm{NPX}(\mathrm{t})-\mu^{\mathrm{N}} \times \mathrm{S}(\mathrm{t}) \\
& \partial \mathrm{I}(\mathrm{t}) / \partial \mathrm{t}=\beta\left(\mathrm{I}(\mathrm{t}) \times \mathrm{S}(\mathrm{t})-(\gamma+\zeta) \times \mathrm{I}(\mathrm{t})+\lambda^{\mathrm{I}} \times \mathrm{NPX}(\mathrm{t})\right. \\
& \partial \mathrm{R}(\mathrm{t}) / \partial \mathrm{t}=\gamma \times \mathrm{I}(\mathrm{t})-\mu^{\mathrm{N}} \times \mathrm{R}(\mathrm{t})+\lambda^{\mathrm{R}} \times \mathrm{NPX}(\mathrm{t}) \\
& \partial \mathrm{D}(\mathrm{t}) / \partial \mathrm{t}=\mu \times \mathrm{I}(\mathrm{t}) \\
& \partial \mathrm{N}(\mathrm{t}) / \partial \mathrm{t}=\mu^{\mathrm{N}} \times \mathrm{S}(\mathrm{t})+\mu^{\mathrm{N}} \times \mathrm{R}(\mathrm{t})
\end{aligned}
$$

where $\mu^{\mathrm{N}}$ represents the natural mortality rate and $\lambda^{\text {st }}$ the rates coming from the exogenous system to the state st.

If TPOB is the initial total population, and it is constant over time, $\operatorname{NPX}(t)=0$, the model meets the hypothesis that at all times 
$\mathrm{S}(\mathrm{t})+\mathrm{I}(\mathrm{t})+\mathrm{R}(\mathrm{t})+\mathrm{D}(\mathrm{t})+\mathrm{N}(\mathrm{t})=1$

If $\operatorname{NPX}(t)$ is different from zero the previous equation must be adjusted as

$$
\mathrm{S}(\mathrm{t})+\mathrm{I}(\mathrm{t})+\mathrm{R}(\mathrm{t})+\mathrm{D}(\mathrm{t})+\mathrm{N}(\mathrm{t})=1+\int_{\mathrm{q} \in[0, \mathrm{t}]} \partial \mathrm{NPX}(\mathrm{q}) \partial \mathrm{q}
$$

To simulate the process the border conditions at the beginning of the simulation horizon are $\mathrm{S}(0), \mathrm{I}(0), \mathrm{R}(0), \mathrm{D}(0)$ and $\mathrm{NPX}(\mathrm{t})$, for all $\mathrm{t}$.

Assuming NPX $(t)$ equal to zero, the ratio $\rho=\gamma / \beta$ is called the relative removal rate. Thus, dynamics of infectious depends on the following ratio:

$$
\mathrm{R}_{0}=\mathrm{S}(0) \times \gamma / \beta
$$

where $\mathrm{R}_{0}$, called the basic reproduction ratio/number, is defined as the number of secondary infections produced by a single infectious individual during his/her entire infectious period. The role of the basic reproduction number is especially important. However, the following mathematical analysis describes how the basic reproduction number depends on the host population and the infected host.

At time $\mathrm{t}=0, \partial \mathrm{I} / \partial \mathrm{t}$ can be written as

$$
\partial \mathrm{I} / \partial \mathrm{t}=\left(\mathrm{R}_{0}-1\right) \times \gamma \times \mathrm{I}(0)
$$

if $\mathrm{R}_{0}>1$ then $\partial \mathrm{t} / \partial \mathrm{t}>0$ and therefore the disease can spread; but if $\mathrm{R}_{0}<1$ then the disease dies out. Making mathematical manipulation it is possible to prove that the maximum number of infective at any time is

$$
\text { TPOB } \times(1-\rho+\rho \ln [\rho / S(0)]))
$$

\subsection{SEIR Epidemic Model}

The classic SEIR model describes the epidemic dynamics based on the transitions between four different epidemic states: susceptible (S), exposed (E), infectious (I), and recovered (R) individuals. The SEIR symbols are the same SIR symbols plus the parameter $y$ that represents the inverse of the virus latency/incubation period (k). There are multiple versions of the SEIR model, some of the literature consulted: Radulescu \& Cavanagh (2020), Hethcote, H. W. (2000), Carcione et a. (2020), Pang, W. (2020), Liu and Liang (2013), Grimm et al. (2020). 
Figure 4. STATE TRANSITION DIAGRAM - SEIR MODEL

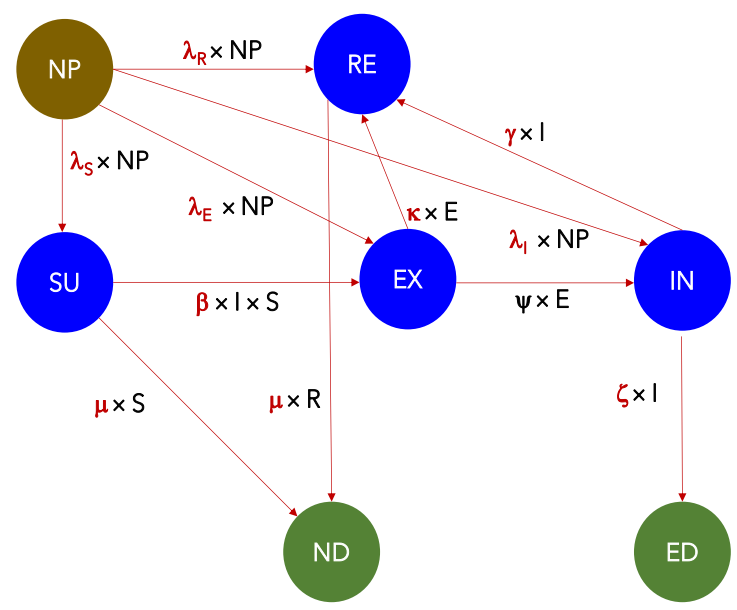

\begin{tabular}{|c|l|}
\hline STATE & \multicolumn{1}{|c|}{ DESCRIPTION } \\
\hline NP & New Population \\
\hline SU & Susceptive Population \\
\hline EX & Exposed Population \\
\hline IN & Infective Population \\
\hline RE & Recovered Population \\
\hline ND & Natural Dead \\
\hline ED & Epidemic Dead \\
\hline
\end{tabular}

The equations of SEIR model are the same as those of SIR model considering the following changes:

$$
\begin{aligned}
& \left.\partial \mathrm{E}(\mathrm{t}) / \partial \mathrm{t}=\beta \times \mathrm{I}(\mathrm{t}) \times \mathrm{S}(\mathrm{t})-\psi \times \mathrm{E}(\mathrm{t})+\lambda^{\mathrm{E}} \times \mathrm{NPX}(\mathrm{t})\right) \\
& \left.\partial \mathrm{I}(\mathrm{t}) / \partial \mathrm{t}=\psi \times \mathrm{E}(\mathrm{t})-(\gamma+\zeta) \times \mathrm{I}(\mathrm{t})+\lambda^{\mathrm{I}} \times \mathrm{NPX}(\mathrm{t})\right)
\end{aligned}
$$

\subsection{SEIMR Epidemic Model}

SEIMR is a generalization of the SEI3RD epidemic model that was developed with the aim of simulating the transmission and evolution of acute infections. This simulation assumes that the pathogen causes an infection followed by lifelong immunity or death. Two versions of SEI3RD were revised: Grimm et al. (2020) and Mejía Becerra et al. (2020), last version is used in this document.

In SEI3RD models the classic SEIR model is extended to distinguish between:

i. Several categories of infectiousness; for example: asymptomatic, symptomatic, moderate, and severe cases

ii. Recovered and dead people.

Being able to explicitly distinguish these different groups is important as they can greatly differ in terms of their underlying parameters as well as in terms of their behavioral response to public health interventions compared with the SEIR Model. 
Figure 5. STATE TRANSITION DIAGRAM - SEI3RD / SEIMRD EPIDEMIC MODELS

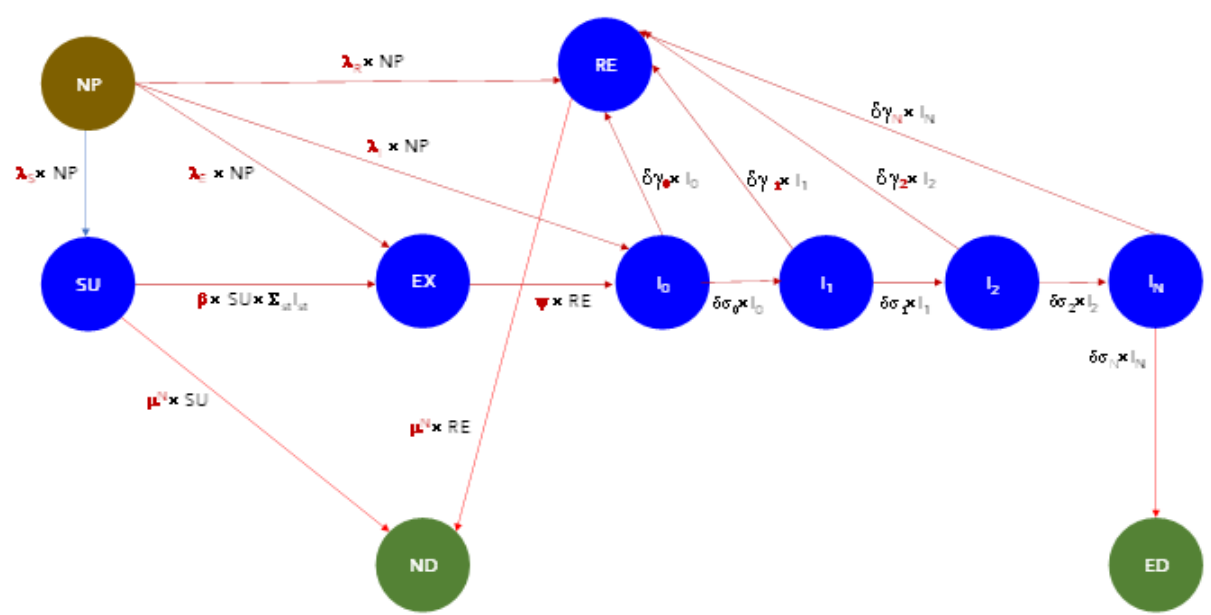

The transition between infected states follows this assumptions:

- A person can only be infected by one of the individuals belonging to one of the infected states $\left(\mathrm{I}_{0}, \mathrm{I}_{1}, \mathrm{I}_{2}, \mathrm{I}_{3}, \ldots, \mathrm{I}_{\mathrm{N}}\right)$. In advance, it will be used the index st that is equivalent to index $i$.

- Being inoculated by the pathogen, the individual passes to the group of exposed $\mathrm{E}$.

- After the latency period, the person in the exposed state becomes asymptomatic infectious ( $\mathrm{I}_{0}$ state).

- Once the person is in $I_{\text {st }}$ state, there are two possible outcomes: worsening clinical status (moving to mild/moderate/critical infected $\left.\mathrm{I}_{\mathrm{st}+1}\right)$ or recovery $(\mathrm{R})$.

- If the person recovers, in any of the states of infection, they enter the absorbent recover state $(\mathrm{R})$.

- Similar logic applies for a larger number of states of infection. It is understood that if an individual of the last state of infection (I3) worsens its clinical condition if it die (E). 
Next table shows the biological parameters of SEI3RD epidemic model.

\begin{tabular}{|c|l|c|c|}
\hline \multicolumn{3}{|c|}{ Table 8. Biological Parameters - SEI3RD Model } \\
\hline Parameter & \multicolumn{1}{|c|}{ Description } & Equation & $\begin{array}{c}\text { Measure } \\
\text { Unit }\end{array}$ \\
\hline $\mathrm{m}^{\mathrm{N}}$ & Natural mortality rate & & fpo/day \\
\hline $\mathrm{k}$ & $\begin{array}{l}\text { The latency period of the virus before } \\
\text { developing }\end{array}$ & day \\
\hline $\mathrm{m}$ & Epidemic mortality rate & & fpo/day \\
\hline $\mathrm{w}$ & Probability of that a person may be contagion & & prob \\
\hline $\mathrm{d}_{\mathrm{st}}$ & Probability of $\mathrm{I}_{0}, \mathrm{I}_{1}, \mathrm{I}_{2}, \mathrm{I}_{3}, \ldots$ of recovering & & prob \\
\hline $\mathrm{p}_{\mathrm{st}}$ & Time a patient in $\mathrm{I}_{0}, \mathrm{I}_{1}, \mathrm{I}_{2}, \mathrm{I}_{3}, \ldots$ recovers & & day \\
\hline $\mathrm{h}_{\mathrm{st}}$ & $\begin{array}{l}\text { Time a patient in } \mathrm{I}_{0}, \mathrm{I}_{1}, \mathrm{I}_{2}, \mathrm{I}_{3}, \ldots \text { to next } \\
\text { infected state }\end{array}$ & & day \\
\hline $\mathrm{z}_{\mathrm{st}}$ & Total contact free rate in $\mathrm{I}_{1}, \mathrm{I}_{2}, \mathrm{I}_{3}, \ldots$ & & $1 /$ day \\
\hline $\mathrm{c}_{\mathrm{st}}$ & $\begin{array}{l}\text { Free probability of contagion in state } \mathrm{I}_{1}, \mathrm{I}_{2}, \mathrm{I}_{3}, \\
\ldots\end{array}$ & & Prob \\
\hline $\mathrm{g}_{\mathrm{st}}$ & Fraction of people who recover in one day & $1 / \mathrm{p}_{\mathrm{st}}$ & fpo/day \\
\hline $\mathrm{s}_{\mathrm{st}}$ & Fraction of people who develops symptoms & $1 / \mathrm{h}_{\mathrm{st}}$ & fpo/day \\
\hline $\mathrm{b}_{\mathrm{st}}$ & $\mathrm{I}_{0}, \mathrm{I}_{1}, \mathrm{I}_{2}, \mathrm{I}_{3}, \ldots$ state transmissibility free rate & $-\mathrm{z}_{\mathrm{st}} \log \left(1-\mathrm{c}_{\mathrm{st}}\right)$ & fpo/day \\
\hline $\mathrm{y}$ & Inverse virus latency period & $1 / \mathrm{k}$ & $1 /$ day \\
\hline
\end{tabular}

It should be noted that there are differences in the equations related to transmissibility rate between the formulation presented by Mejía Becerra et al. (2020) and the standard formulations for SIR and SEIR models.

It is important to understand the relationship between the probability of recovery, the recovery/worsening time, and the rate of departure of people from a state. The output rate from one state to another state may be based on the following expression:

Output Rate to State (st) = Output Probability to State (st) / Departure Time to State (st)

The total exit rate to any state implies the sum of exit rates to all states. Output Rate $=S_{\text {st }}$ Output Rate to State (st)

The SEI3RD equations (Mejía Becerra et al., 2020) of the dynamic model described previously symbolize the proportion of individuals in the population in each of the states $\left(\mathrm{S}, \mathrm{E}, \mathrm{I}_{\mathrm{i}}, \mathrm{R}\right.$ and $\left.\mathrm{D}\right)$, they are:

$$
\begin{aligned}
& \partial \mathrm{S}(\mathrm{t}) / \partial \mathrm{t}=-\mathrm{S}(\mathrm{t})\left(\beta_{0}(\mathrm{t}) \times \mathrm{I}_{0}(\mathrm{t})+\beta_{1}(\mathrm{t}) \times \mathrm{I}_{1}(\mathrm{t})+\beta_{2} \times \mathrm{I}_{2}(\mathrm{t})+\beta_{3} \times \mathrm{I}_{3}(\mathrm{t})\right) \\
& \partial \mathrm{E}(\mathrm{t}) / \partial \mathrm{t}=\mathrm{S}(\mathrm{t})\left(\beta_{0}(\mathrm{t}) \times \mathrm{I}_{0}(\mathrm{t})+\beta_{1}(\mathrm{t}) \times \mathrm{I}_{1}(\mathrm{t})+\beta_{2} \times \mathrm{I}_{2}(\mathrm{t})+\beta_{3} \times \mathrm{I}_{3}(\mathrm{t})\right)-\psi \times \\
& \mathrm{E}(\mathrm{t}) \\
& \partial \mathrm{I}_{0}(\mathrm{t}) / \partial \mathrm{t}=\psi \times \mathrm{E}(\mathrm{t})-\delta_{0} \times \gamma_{0} \times \mathrm{I}_{0}(\mathrm{t})-\left(1-\delta_{0}\right) \times \sigma_{0} \times \mathrm{I}_{0}(\mathrm{t}) \\
& \left.\partial \mathrm{I}_{1}(\mathrm{t}) / \partial \mathrm{t}=\left(1-\delta_{0}\right) \times \sigma_{0} \times \mathrm{I}_{0}(\mathrm{t})-\delta_{1} \times \gamma_{1} \times \mathrm{I}_{1}(\mathrm{t})-\left(1-\delta_{1}\right) \times \sigma_{1} \times \mathrm{I}_{1}(\mathrm{t})\right) \\
& \partial \mathrm{I}_{2}(\mathrm{t}) / \partial \mathrm{t}=\left(1-\delta_{1}\right) \times \sigma_{1} \times \mathrm{I}_{1}(\mathrm{t})-\delta_{2} \times \gamma_{2} \times \mathrm{I}_{2}(\mathrm{t})-\left(1-\delta_{2}\right) \times \sigma_{2} \times \mathrm{I}_{2}(\mathrm{t}) \\
& \partial \mathrm{I}_{3}(\mathrm{t}) / \partial \mathrm{t}=\left(1-\delta_{2}\right) \times \sigma_{2} \times \mathrm{I}_{2}(\mathrm{t})-\delta_{3} \times \gamma_{3} \times \mathrm{I}_{3}(\mathrm{t})-\left(1-\delta_{3}\right) \times \sigma_{3} \times \mathrm{I}_{3}(\mathrm{t}) \\
& \partial \mathrm{R}(\mathrm{t}) / \partial \mathrm{t}=\delta_{0} \times \gamma_{0} \times \mathrm{I}_{0}(\mathrm{t})+\delta_{1} \times \gamma_{1} \times \mathrm{I}_{1}(\mathrm{t})+\delta_{2} \times \gamma_{2} \times \mathrm{I}_{2}(\mathrm{t})+\delta_{3} \times \gamma_{3} \times \mathrm{I}_{3}(\mathrm{t}) \\
& \partial \mathrm{D}(\mathrm{t}) / \partial \mathrm{t}=\left(1-\delta_{3}\right) \times \sigma_{3} \times \mathrm{I}_{3}(\mathrm{t})
\end{aligned}
$$


The following specification must be considered:

1. $\mathrm{y}$ is the reciprocal of the average latency period.

2. $\mathrm{d}_{\mathrm{st}}$ is the likelihood (probability) that an individual in group $\mathrm{I}_{\mathrm{st}}$ will recover without worsening their clinical condition. This version of SERI3D considers that the people only death, for epidemic reasons, in the last infected state. This limitation may be relaxed but it implies the estimation of more parameters. Then, $\mathrm{m}$ the mortality rate is equal to $\mathrm{d}_{\mathrm{st}}$, for st equal to the last infected state.

3. $\mathrm{g}_{\mathrm{st}}$ is the reciprocal of the average recovery time, without worsening its clinical state, of an individual of class $\mathrm{I}_{\mathrm{st}}$.

4. $\mathrm{s}_{\mathrm{st}}$ is the reciprocal of the average complication time of a patient in the $\mathrm{I}_{\mathrm{st}}$ state.

5. $b_{\text {st }}$ is the transmissibility rate of an individual in state $\mathrm{I}_{\mathrm{st}}$. must be noted that Mejía Becerra et al. (2020) includes transmissibility rates related with the epidemic control policies, this is ignored in this document

Then, the equations of SEI3RD model are the same as those of the previous SEIR model considering the following changes:

$$
\begin{aligned}
& \partial \mathrm{S}(\mathrm{t}) / \partial \mathrm{t}=-\left[\Sigma_{\mathrm{st} \in \mathrm{INF}} \beta_{\mathrm{st}} \times \mathrm{I}_{\mathrm{st}}(\mathrm{t})\right] \times \mathrm{S}(\mathrm{t})+\lambda^{\mathrm{S}} \times \mathrm{NPX}(\mathrm{t})-\mu^{\mathrm{N}} \times \mathrm{S}(\mathrm{t}) \\
& \partial \mathrm{E}(\mathrm{t}) / \partial \mathrm{t}=\left[\Sigma_{\mathrm{st} \in \mathrm{INF}} \beta_{\mathrm{st}} \times \mathrm{I}_{\mathrm{st}}(\mathrm{t})\right] \times \mathrm{S}(\mathrm{t})-\psi \times \mathrm{E}(\mathrm{t})+\lambda^{\mathrm{E}} \times \mathrm{NPX}(\mathrm{t}) \\
& \partial \mathrm{I}_{0}(\mathrm{t}) / \partial \mathrm{t}=\psi \times \mathrm{E}(\mathrm{t})-\delta \delta_{0} \times \mathrm{I}_{0}(\mathrm{t})+\lambda^{\mathrm{I}} \times \mathrm{NPX}(\mathrm{t}) \\
& \partial \mathrm{I}_{\mathrm{st}}(\mathrm{t}) / \partial \mathrm{t}=\delta \sigma_{\text {st }-1} \times \mathrm{I}_{\mathrm{st}-1}(\mathrm{t})-\delta \delta_{\text {st }} \times \mathrm{I}_{\mathrm{st}}(\mathrm{t}) \\
& \partial \mathrm{R}(\mathrm{t}) / \partial \mathrm{t}=\Sigma_{\mathrm{st} \in \mathrm{INF}} \delta \gamma_{\mathrm{st}} \times \mathrm{I}_{\mathrm{st}}(\mathrm{t})-\mu^{\mathrm{N}} \times \mathrm{R}(\mathrm{t})+\lambda^{\mathrm{R}} \times \mathrm{NPX}(\mathrm{t}) \\
& \partial \mathrm{D}(\mathrm{t}) / \partial \mathrm{t}=\Sigma_{\mathrm{st} \in \mathrm{IF}} \delta \sigma_{\mathrm{st}} \times \mathrm{I}_{\mathrm{st}}(\mathrm{t})
\end{aligned}
$$

The following relations should be considered:

- Equation $\partial \mathrm{I}_{\mathrm{st}}(\mathrm{t}) / \partial \mathrm{t}$ valid for $\mathrm{st} \in \mathrm{I} 1 \mathrm{~F}$ (the set of infected states excluding the first infected state, $\mathrm{I}_{0}$ )

- $s t \in \mathrm{INF}$ is the set of all infected states

- $s t \in I F$ is the set associated to the last infected state.

The following definitions (auxiliary parameters) was included

$$
\begin{aligned}
& \sigma \delta_{\mathrm{st}}=\delta_{\mathrm{st}} \times \sigma_{\mathrm{st}} \\
& \delta \sigma_{\mathrm{st}}=\left(1-\delta_{\mathrm{st}}\right) \times \sigma_{\mathrm{st}}=\sigma_{\mathrm{st}}-\sigma \delta_{\mathrm{st}} \\
& \delta \gamma_{\mathrm{st}}=\delta_{\mathrm{st}} \times \gamma_{\mathrm{st}} \\
& \delta \delta_{\mathrm{st}}=\left(\delta_{\mathrm{st}} \times \gamma_{\mathrm{st}}+\left(1-\delta_{\mathrm{st}}\right) \times \sigma_{\mathrm{st}}\right)=\delta \gamma_{\mathrm{st}}+\delta \sigma_{\mathrm{st}} \\
& \mu=\Sigma_{\mathrm{st} \in \mathrm{IF}} \delta \sigma_{\mathrm{st}}
\end{aligned}
$$

The following table resumes the equation included in SEIMR model. The equation has been divided in positive (increment) and negative (decrement) impacts on the state st. 


\begin{tabular}{|c|c|c|c|c|}
\hline \multicolumn{5}{|c|}{ Table 9. SEIMR - Differential Equations } \\
\hline st $\in$ SET & $\begin{array}{c}\text { State } \\
\text { Increment }\end{array}$ & $\begin{array}{c}\text { State } \\
\text { Decrement }\end{array}$ & $\begin{array}{c}\text { Natural } \\
\text { Dead }\end{array}$ & $\begin{array}{l}\text { Exogenous } \\
\text { Increment }\end{array}$ \\
\hline SU & $1^{\mathrm{S}} \times \mathrm{NPX}(\mathrm{t})$ & $\mathrm{IS}(\mathrm{t}) \times \mathrm{S}(\mathrm{t})$ & $\mathrm{m}^{\mathrm{N}} \times \mathrm{S}(\mathrm{t})$ & $1^{\mathrm{S}} \times \mathrm{NPX}(\mathrm{t})$ \\
\hline EX & $\mathrm{IS}(\mathrm{t}) \times \mathrm{S}(\mathrm{t})$ & $\mathrm{y} \times \mathrm{E}(\mathrm{t})$ & & $1^{\mathrm{E}} \times \mathrm{NPX}(\mathrm{t})$ \\
\hline IN & $\mathrm{IS}(\mathrm{t}) \times \mathrm{S}(\mathrm{t})$ & \multirow[t]{3}{*}{$\mathrm{dd}_{\mathrm{st}} \times \mathrm{I}_{\mathrm{st}}(\mathrm{t})$} & & $1^{\mathrm{I}} \times \mathrm{NPX}(\mathrm{t})$ \\
\hline I0 & $\mathrm{y} \times \mathrm{E}(\mathrm{t})$ & & & $\mathrm{I}^{\mathrm{I}} \times \mathrm{NPX}(\mathrm{t})$ \\
\hline $\mathrm{I} 1 \mathrm{~F}$ & $\mathrm{ds}_{\mathrm{st}-1} \times \mathrm{I}_{\mathrm{st}-1}(\mathrm{t})$ & & & \\
\hline $\mathrm{RE}$ & 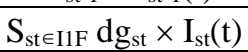 & & $\mathrm{m}^{\mathrm{N}} \times \mathrm{R}(\mathrm{t})$ & $1^{\mathrm{R}} \times \operatorname{NPX}(\mathrm{t})$ \\
\hline \multirow[t]{3}{*}{ ED } & $\mathrm{S}_{\mathrm{st} \in \mathrm{IF}} \mathrm{m} \times \mathrm{I}_{\mathrm{st}}(\mathrm{t})$ & & & \\
\hline & \multicolumn{2}{|c|}{ Auxiliary Equation } & & \\
\hline & \multicolumn{2}{|c|}{$\mathrm{IS}(\mathrm{t})=\left[\mathrm{S}_{\mathrm{st} \in \mathrm{INF}} \mathrm{b}_{\mathrm{st}}(\mathrm{t}) \times \mathrm{I}_{\mathrm{st}}(\mathrm{t})\right]$} & & \\
\hline
\end{tabular}

These equations serve to represent any of the three models studied. The conditions are as follows:

1. SIR Model:

- Only consider one infected state IN the definitions of the infected state sets are:

$s t \in I F=\{I N\}, s t \in I 1 F=\{\}, s t \in I 0=\{\}, s t \in I N F=\{I N\}$ and $s t \in I N=\{I N\}$

- Do not include the exposed state (E), that means that $s t \in E X=\{\}$

2. SEIR Model

- Only consider one infected state IN.

\section{SEIMR Model}

- Considered multiples infected stats $\{\mathrm{I} 0, \mathrm{I} 1, \mathrm{I} 2, \ldots, \mathrm{IN}\} \mathrm{IN}$ associate to $\mathrm{I}_{\mathrm{N}}$, do not include the state $\mathrm{I}_{0}$ that means:

$s t \in I F=\left\{I_{N}\right\}, s t \in I 1 F=\left\{I_{1}, I_{2}, \ldots, I_{N}\right\}, s t \in I 0=\left\{I_{0}\right\}, s t \in I N F=\left\{I_{0}, I_{1}, I_{2}, \ldots\right.$ , $\left.\mathrm{I}_{\mathrm{N}}\right\}$ and $\mathrm{st} \in \mathrm{IN}=\{\mathrm{I}\}$

The next table presents the SETs of epidemic states needed to model the three epidemics models. The infected sets permit to model any of the three models with the same equations; they are used to define the existence conditions of the equations and in summation limits into the equations.

\begin{tabular}{|c|c|c|c|c|c|c|c|c|c|c|c|}
\hline \multicolumn{12}{|c|}{ Table 10. Epidemic States SETs } \\
\hline \multirow[b]{2}{*}{ Model } & Epidemic States & \multicolumn{5}{|c|}{ Non Infected States } & \multicolumn{5}{|c|}{ Infected States } \\
\hline & STA & SU & EX & $\mathrm{RE}$ & ED & ND & INF & $\begin{array}{l}\mathrm{I} \\
\mathrm{N}\end{array}$ & I0 & $\mathrm{I} 1 \mathrm{~F}$ & IF \\
\hline SIR & $\overline{\mathrm{S}, \mathrm{I}, \mathrm{R}, \mathrm{D}, \mathrm{N}}$ & $\bar{S}$ & & $\overline{\mathrm{R}}$ & $\mathrm{D}$ & $\overline{\mathrm{N}}$ & $\overline{\mathrm{I}}$ & II & & & \\
\hline SEIR & $\mathrm{S}, \mathrm{E}, \mathrm{I}, \mathrm{R}, \mathrm{D}, \mathrm{N}$ & $\mathrm{S}$ & $\mathrm{E}$ & $\mathrm{R}$ & $\mathrm{D}$ & $\mathrm{N}$ & I & I & & & \\
\hline SEIMR & $\begin{array}{c}\mathrm{S}, \mathrm{E}, \mathrm{I}_{0}, \mathrm{I}_{1}, \mathrm{I}_{2}, \ldots \mathrm{I}_{\mathrm{N}} \\
\mathrm{D}, \mathrm{N}\end{array}$ & $\mathrm{S}$ & $\mathrm{E}$ & $\mathrm{R}$ & $\mathrm{D}$ & $\mathrm{N}$ & $\begin{array}{c}\mathrm{I}_{0}, \mathrm{I}_{1}, \mathrm{I}_{2} \ldots \\
\mathrm{I}_{\mathrm{N}}\end{array}$ & & $\mathrm{I}_{0}$ & $\begin{array}{c}\mathrm{I}_{1} \\
\mathrm{I}_{2} \ldots \mathrm{I}_{\mathrm{N}-1}\end{array}$ & $\mathrm{I}_{\mathrm{N}}$ \\
\hline
\end{tabular}




\section{SEIMR/R-S General Epidemic Model}

The SEIMR/R-S model is built on the basic equations of the SEIMR model including the effects of considering the development of the epidemic in a territory (macro-region) that includes multiple regions in which the population sociodemographic segments are distributed in a non-homogeneous manner.

\subsection{Framework}

The focus SEIMR/R-S is on building the epidemic modelling with a bottom-up approach, rather than the traditional top-down approach in which multi-region territory (macro-region) is modeled in an aggregated manner and what happens in regions is inferred through disaggregation processes, usually based on empirical rules and mental models.

Figure 6. LOW MATHEMATICAL COMPLEXITY TOP-DOWN MODELING

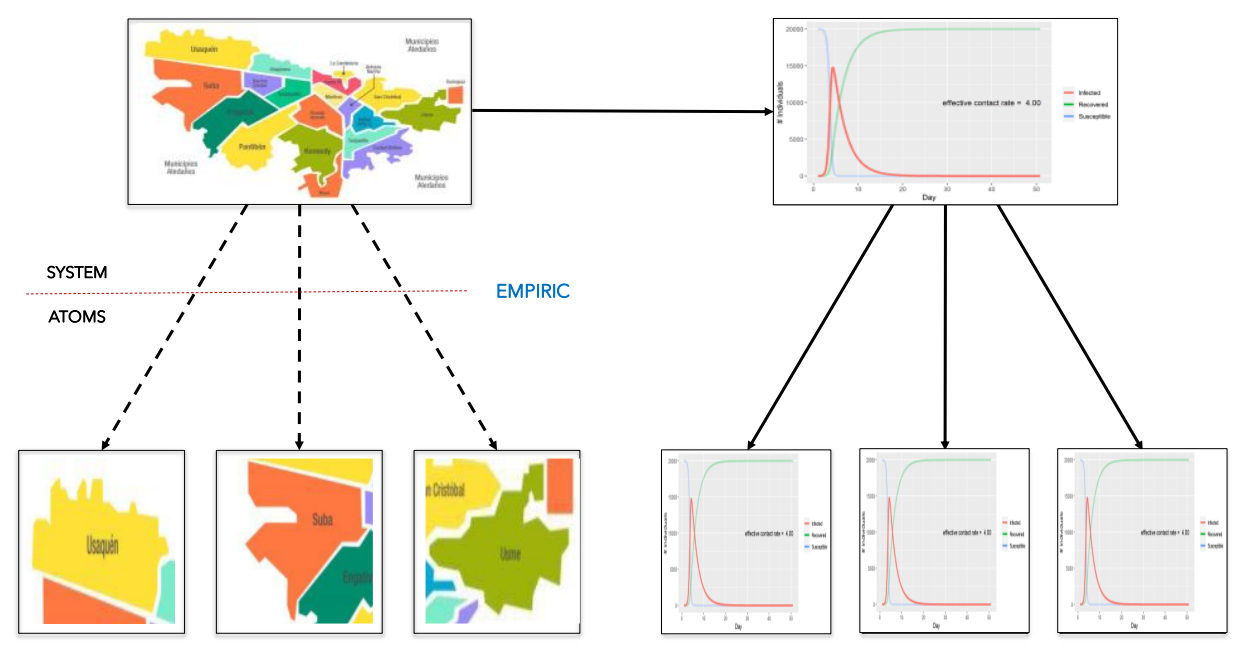

In the bottom-up approach, SEIMR/R-S models what happens in each atom (region-sociodemographic segment) and the relationships that occur between atoms, that in the case of the pandemic focuses on the mobility of people. Modeling is based on the epidemic process characterized by different behavior in each sociodemographic segment (e.g., age and economic stratum) and the distribution of segments in each of the regions, modeling what happens in each <region-segment>. 
Figure 7. HIGH MATHEMATICAL COMPLEXITY BOTTOM-UP MODELING

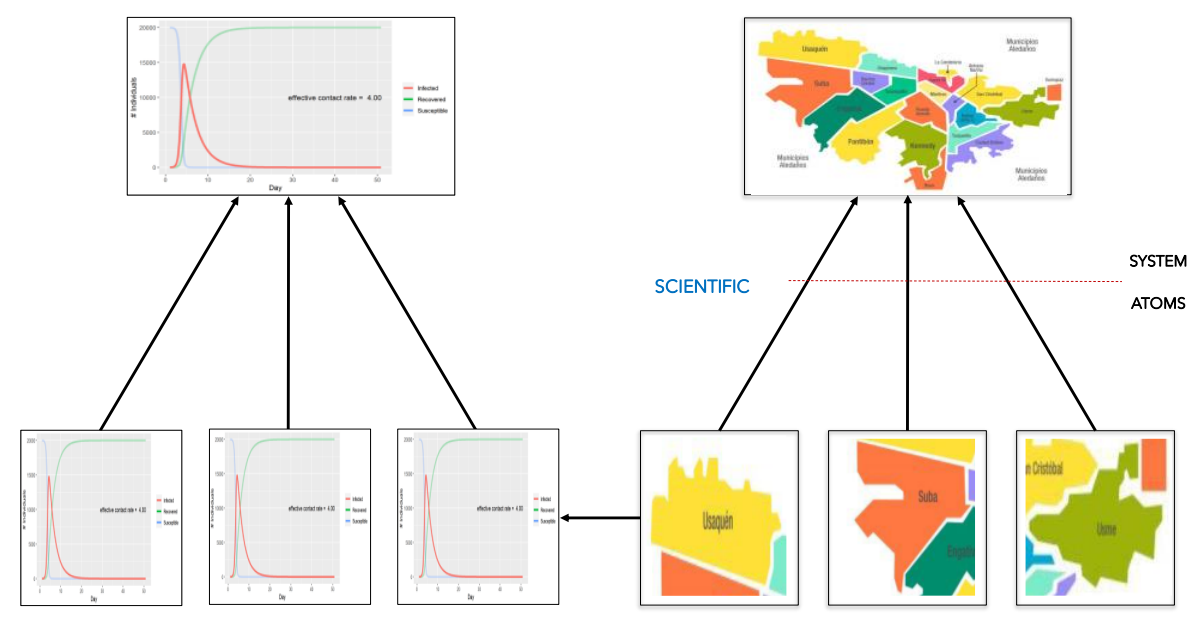

On the other hand, the mobility of the population between regions is characterized by the number and the duration of travels, it could also be considered the closeness of people during the trip, which depends on the transport mode. In this way the epidemic spreads between regions. Only one transport mode is considered in the formulation, but it is straight forward the extension to multiple transport modes.

The mobility is the more important part of SEIMR/R-S, because if it is ignored, the differential equation model would be reduced to NR x NS parallel systems of simultaneous equations without interaction between them, which is not consistent with what happens in reality. NR represents the number of regions and NS represents the number of sociodemographic segments.

Figure 8. MOBILITY BETWEEN REGIONS \& EPIDEMIC STATE
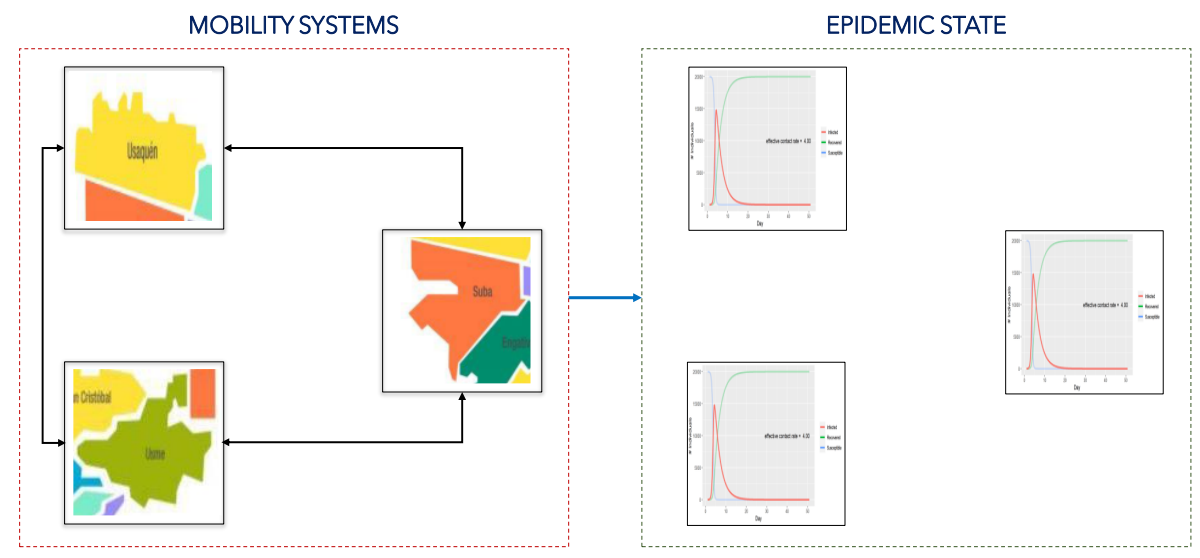
The structure of SEIMR/R-S allows the decision maker to simulate, or optimize, epidemic control policies by acting directly on an <region, segment> atom and/or on a connectivity arc (mode of transport) between regions. This cannot be achieved with traditional top-down modeling.

\subsection{Common Algebraic Notation}

Including regional and sociodemographic segment modeling (in this case age and economic stratum) involves associating the biological parameters with these aspects. Therefore, biological parameters may be related to indices: rg (region), ss (sociodemographic segment), ag (age) and/or se (economic stratum). The next table shows the basic parameters of the SEIMR and SEIMR/R-S and their relationships.

\begin{tabular}{|c|c|c|c|c|}
\hline \multicolumn{5}{|c|}{ Table 11. Biological Parameters - SEI3RD \& SEIMR/R-S Models } \\
\hline SEIMR & \multicolumn{2}{|c|}{ SEIMR/R-S } & \multirow[t]{2}{*}{ Description } & \multirow{2}{*}{$\begin{array}{c}\text { Measure } \\
\text { Unit }\end{array}$} \\
\hline Parameter & Parameter & Source & & \\
\hline $\mathrm{m}^{\mathrm{N}}$ & $\mathrm{m}^{\mathrm{N}}$ & Read & Natural mortality rate & fpo/day \\
\hline $\mathrm{k}$ & $\mathrm{k}$ & Read & $\begin{array}{l}\text { The latency period of the virus before } \\
\text { developing }\end{array}$ & day \\
\hline $\mathrm{m}$ & $\mathrm{m}_{\mathrm{ag}}$ & Model & Epidemic mortality rate & fpo/day \\
\hline $\mathrm{W}$ & $\mathrm{W}_{\mathrm{rg}, \mathrm{ss}}$ & Model & $\begin{array}{c}\text { Probability of that a person may be } \\
\text { contagion }\end{array}$ & prob \\
\hline$\delta_{\mathrm{st}}$ & $\delta_{\text {ag,st }}$ & Model & $\begin{array}{l}\text { Probability of } \mathrm{I}_{0}, \mathrm{I}_{1}, \mathrm{I}_{2}, \mathrm{I}_{3}, \ldots \text { of } \\
\text { recovering }\end{array}$ & prob \\
\hline $\mathrm{p}_{\mathrm{st}}$ & $\mathrm{p}_{\mathrm{ag}, \mathrm{st}}$ & Model & $\begin{array}{l}\text { Time a patient in } \mathrm{I}_{0}, \mathrm{I}_{1}, \mathrm{I}_{2}, \mathrm{I}_{3}, \ldots \\
\text { recovers }\end{array}$ & day \\
\hline $\mathrm{h}_{\mathrm{st}}$ & $\mathrm{h}_{\mathrm{ag}, \mathrm{st}}$ & Model & $\begin{array}{c}\text { Time a patient in } \mathrm{I}_{0}, \mathrm{I}_{1}, \mathrm{I}_{2}, \mathrm{I}_{3}, \ldots \text { to next } \\
\text { infected state }\end{array}$ & day \\
\hline $\mathrm{b}_{\mathrm{st}}$ & $\mathrm{b}$ & Model & $\begin{array}{l}\text { Transmissibility rate of an individual in } \\
\text { state st }\end{array}$ & \\
\hline $\mathrm{Z}_{\mathrm{st}}$ & $\mathrm{Z}$ & Model & Total contact free rate in $\mathrm{I}_{1}, \mathrm{I}_{2}, \mathrm{I}_{3}, \ldots$ & $1 /$ day \\
\hline $\mathrm{c}_{\mathrm{st}}$ & $\mathrm{c}_{\mathrm{ag}, \mathrm{st}}$ & Model & $\begin{array}{l}\text { Free probability of contagion in state } \mathrm{I}_{1} \text {, } \\
\qquad \mathrm{I}_{2}, \mathrm{I}_{3}, \ldots\end{array}$ & prob \\
\hline
\end{tabular}

The source Model indicates that parameters should be the result of the mathematical model of parameters to be constructed from the regional distribution of sociodemographic segments and their characterization from specific studies developed for the macro-region. In advance this model will be referred as Parameters Model which must be built on the basis of the territory's sociodemographic information system. An example of the database built for the city of Bogota is located at: http://www.doanalytics.net/Documents/DW-2A-ITM-SEIMR-R-SEpidemic-Model-Case-Bogota.pdf 
The following diagram presents the connectivity of the SEIMR/R-S model use process to be used as a pandemic simulation tool under different control policies studied by the decision maker.

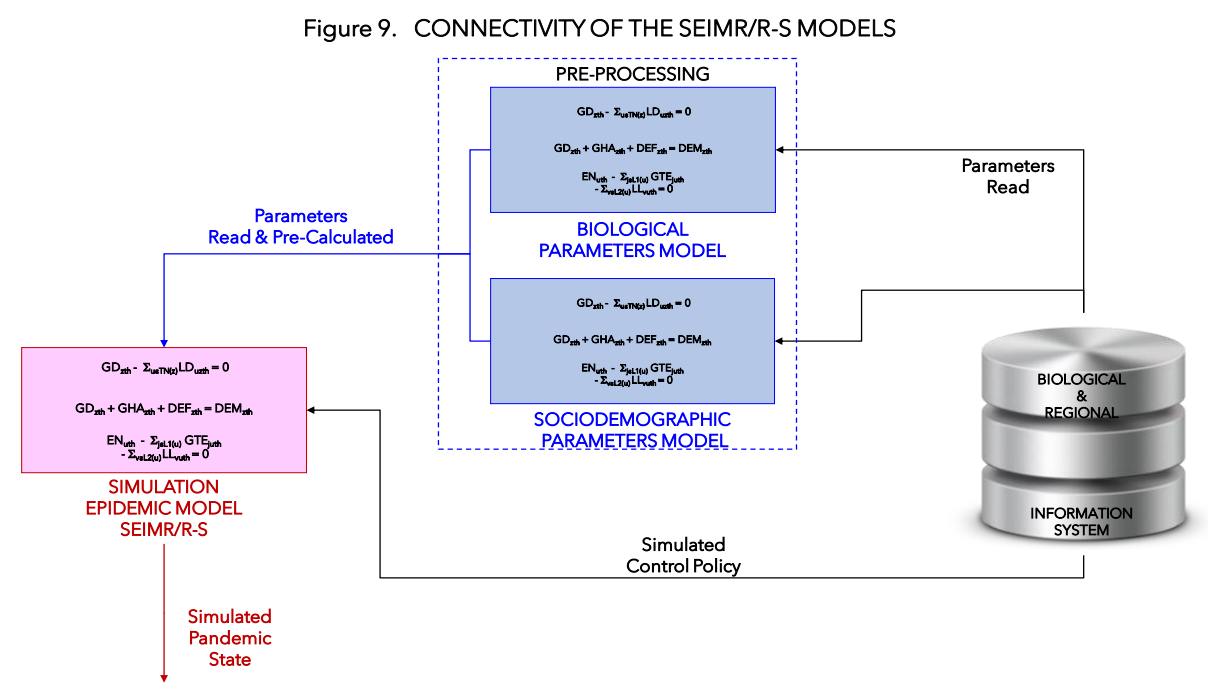

Because the variability of the SEI3RD parameters is simpler than that of the SEIMR/R-S parameters it is possible to replace the SEIMR/R-S parameters with the SEIMR to have an equivalent model, but less explanatory of the details that differentiate the epidemic process in the regions.

The calculated biological parameters used in SEIMR/R-S model is presented below; they are divided in basic and auxiliary parameters that are included to make easier the implementation process.

\begin{tabular}{|c|c|c|c|c|c|}
\hline \multicolumn{6}{|c|}{ Table 12. Biological Parameters (Calculated) - SEIMR/R-S Model } \\
\hline \multicolumn{2}{|c|}{ SEIMR } & \multicolumn{2}{|c|}{ SEIMR/R-S } & \multirow[t]{2}{*}{ Description } & \multirow{2}{*}{$\begin{array}{c}\text { Measure } \\
\text { Unit }\end{array}$} \\
\hline Parameter & Equation & Parameter & Equation & & \\
\hline $\mathrm{g}_{\mathrm{st}}$ & $1 / \mathrm{p}_{\mathrm{st}}$ & $\mathrm{g}_{\mathrm{ag}, \mathrm{st}}$ & $1 / p_{a g, s t}$ & $\begin{array}{l}\text { Fraction of people recovered } \\
\text { in } 1 \text { day }\end{array}$ & fpo/day \\
\hline $\mathrm{S}_{\mathrm{st}}$ & $1 / \mathrm{h}_{\mathrm{st}}$ & $\mathrm{S}_{\mathrm{ag}, \mathrm{st}}$ & $1 / h_{\mathrm{ag}, \mathrm{st}}$ & $\begin{array}{c}\text { Fraction of people develops } \\
\text { symptoms }\end{array}$ & fpo/day \\
\hline $\mathrm{b}_{\mathrm{st}}$ & $\begin{array}{c}-\xi_{\mathrm{st}} \log (1 \\
\left.-\mathrm{c}_{\mathrm{st}}\right)\end{array}$ & $\mathrm{b}_{\mathrm{st}}$ & $\begin{array}{c}-\xi_{\mathrm{st}} \log (1- \\
\left.c_{\mathrm{ag}, \mathrm{st}}\right)\end{array}$ & $\begin{array}{c}\mathrm{I}_{0}, \mathrm{I}_{1}, \mathrm{I}_{2}, \mathrm{I}_{3}, \ldots \text { state } \\
\text { transmissibility rate }\end{array}$ & fpo/day \\
\hline $\mathrm{y}$ & $1 / \mathrm{k}$ & $\mathrm{y}$ & $1 / \mathrm{k}$ & Inverse virus latency period & 1/day \\
\hline $\mathrm{sd}_{\mathrm{st}}$ & $\mathrm{d}_{\mathrm{st}} \mathrm{s}_{\mathrm{st}}$ & $\mathrm{sd}_{\mathrm{ag}, \mathrm{st}}$ & $\mathrm{d}_{\mathrm{ag}, \mathrm{st}} \mathrm{S}_{\mathrm{ag}, \mathrm{st}}$ & $\mathrm{d}_{\mathrm{ag}, \mathrm{st}} \mathrm{s}_{\mathrm{ag}, \mathrm{st}}$ & \\
\hline $\mathrm{ds}_{\mathrm{st}}$ & $\left(1-d_{s t}\right) s_{s t}$ & $\mathrm{ds}_{\mathrm{ag}, \mathrm{st}}$ & $\begin{array}{c}\left(1-d_{a g, s t}\right) \\
s_{a g, s t} \\
\end{array}$ & $\left(1-d_{a g, s t}\right) s_{a g, s t}$ & \\
\hline $\mathrm{dg}_{\mathrm{st}}$ & $\mathrm{d}_{\mathrm{st}} \mathrm{g}_{\mathrm{st}}$ & $\mathrm{dg}_{\mathrm{ag}, \mathrm{st}}$ & $\mathrm{d}_{\mathrm{ag}, \mathrm{st}} \mathrm{g}_{\mathrm{ag}, \mathrm{st}}$ & $\mathrm{d}_{\mathrm{ag}, \mathrm{st}} \mathrm{g}_{\mathrm{ag}, \mathrm{st}}$ & \\
\hline $\mathrm{dd}_{\mathrm{st}}$ & $\mathrm{dg}_{\mathrm{st}}+\mathrm{ds}_{\mathrm{st}}$ & $\mathrm{dd}_{\mathrm{ag}, \mathrm{st}}$ & $\begin{array}{c}\mathrm{dg}_{\mathrm{ag}, \mathrm{st}}+ \\
\mathrm{ds}_{\mathrm{ag}, \mathrm{st}}\end{array}$ & $\mathrm{dg}_{\mathrm{ag}, \mathrm{st}}+\mathrm{ds}_{\mathrm{ag}, \mathrm{st}}$ & \\
\hline $\mathrm{m}$ & $\mathrm{S}_{\mathrm{st} \in \mathrm{IF}} \mathrm{ds}_{\mathrm{st}}$ & $\mathrm{m}_{\mathrm{ag}}$ & $\mathrm{S}_{\mathrm{st} \in \mathrm{IF}} \mathrm{ds}_{\mathrm{ag}, \mathrm{st}}$ & $S_{\mathrm{st} \in \mathrm{IF}} \mathrm{ds}_{\mathrm{ag}, \mathrm{st}}$ & \\
\hline
\end{tabular}




\begin{tabular}{|c|c|c|c|c|c|}
\hline & $\mathrm{br}_{\mathrm{rg}, \mathrm{ss}}$ & Model & $\begin{array}{c}\text { Contagion probability } \\
\text { function of regional and } \\
\text { sociodemographic }\end{array}$ & prob \\
\hline & $\mathrm{bb}_{\mathrm{rg}, \mathrm{ss}}$ & $\begin{array}{c}\mathrm{S}_{\mathrm{ag} \in \mathrm{AGS}(\mathrm{ss})} \\
\mathrm{dd}_{\mathrm{ag}, \mathrm{st}} \times \\
\mathrm{br}_{\mathrm{rg}, \mathrm{ss}}\end{array}$ & $\begin{array}{c}\text { Inverse contact intensity by } \\
\text { infectivity }\end{array}$ & $\begin{array}{c}1 / \mathrm{fpo}- \\
\text { day }\end{array}$ \\
\hline
\end{tabular}

\subsection{Regional-Segment Modeling}

\subsubsection{Regional Modeling}

To formulate the regional model segmented sociodemographically the following hypotheses are assumed:

1. There is no direct contagion between people living in different regions. This can be true for large regions such as states or departments. But it is questionable for metropolitan areas (cities and conurbed regions) where there is intense traffic between regions that must be represented by the mobility system.

2. The inter-region interrelationship is modeled on the following assumptions:

- There is traffic of people between regions, which sets for each pair of regions the fraction of each segment, $\mathrm{j}_{\mathrm{ro}, \mathrm{rg}, \mathrm{ss}}$, moving from the source region (ro) to the destination region ( $\mathrm{rg}$ ).

- In addition, the fraction of the time, $\mathrm{f}_{\mathrm{ro}, \mathrm{rg}, \mathrm{ss}}$, is known to people from the region origin in the destination region during the period (one day).

3. Modeling does not include different modes of inter-region transport. One way to include this aspect is to associate the tm-index with the entity transport mode and differentiate the population by means of the transport mode that they use, which involves redefining the parameter $\mathrm{j}_{\mathrm{ro}, \mathrm{rg}, \mathrm{ss}}$ as a

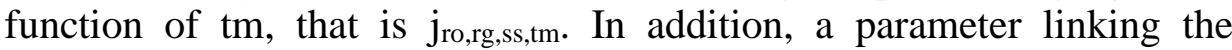
closeness of people during the trip should be included, which should increase the likelihood of contagion that should be inversely proportional to closeness.

The calculation process involves determining the impact on the spread of the virus that the population movement has for this purpose it is calculated using the number of infected people who can move between two regions multiplied by the fraction of the time spent in the destination locality. This implies the following effects on the diffusion rate:

1. Infected Movements

- Increasing the rate of diffusion in the destination locality due to those infected by coming from other regions, it is calculated as:

$\mathrm{II}_{\mathrm{rg}}(\mathrm{t})=\mathrm{S}_{\mathrm{ss} \in \mathrm{SSR}(\mathrm{rg})} \mathrm{S}_{\mathrm{ro} \in \mathrm{ROR}(\mathrm{rg})} \mathrm{j}_{\mathrm{ro}, \mathrm{rg}, \mathrm{ss}} \times \mathrm{f}_{\mathrm{ro}, \mathrm{rg}, \mathrm{ss}} \times \mathrm{IS}_{\mathrm{ro}, \mathrm{ss}}(\mathrm{t})$

- Decreased diffusion rate in the source region due to the infected by moving to other regions, it is calculated as:

$\operatorname{IE}_{\mathrm{rg}}(\mathrm{t})=\mathrm{S}_{\mathrm{ss} \in \mathrm{SSR}(\mathrm{rg})} \mathrm{S}_{\mathrm{rd} \in \mathrm{RDE}(\mathrm{rg})} \mathrm{j}_{\mathrm{rg}, \mathrm{rd}, \mathrm{ss}} \times \mathrm{f}_{\mathrm{rg}, \mathrm{rd}, \mathrm{ss}} \times \mathrm{IS}_{\mathrm{rg}, \mathrm{ss}}(\mathrm{t})$ 
The net effect on the rg-region will be:

$$
\begin{gathered}
\operatorname{IS}_{\mathrm{rg}, \mathrm{ss}}(\mathrm{t})=\mathrm{S}_{\mathrm{st} \in \mathrm{INF}} \mathrm{I}_{\mathrm{st}, \mathrm{rg}, \mathrm{ss}}(\mathrm{t}) \\
\operatorname{IX}_{\mathrm{rg}}(\mathrm{t})=\mathrm{S}_{\mathrm{ss} \in \operatorname{SSR}(\mathrm{rg})} \mathrm{IS}_{\mathrm{rg}, \mathrm{ss}}(\mathrm{t}) \\
\operatorname{IR}_{\mathrm{rg}}(\mathrm{t})=\mathrm{IX}_{\mathrm{rg}}(\mathrm{t})+\mathrm{II}_{\mathrm{rg}}(\mathrm{t})-\operatorname{IE}_{\mathrm{rg}}(\mathrm{t}) \\
\text { where }
\end{gathered}
$$

$\mathrm{I}_{\mathrm{st}, \mathrm{rg}, \mathrm{ss}}(\mathrm{t})$ fraction of the population infected in st-epidemic-state living in rg-region and ss-segment.

$\mathrm{IS}_{\mathrm{rg}, \mathrm{ss}}(\mathrm{t})$ fraction of the population infected living in rg-region and ss-segment.

$\operatorname{IX}_{\mathrm{rg}}(\mathrm{t}) \quad$ fraction of the population infected living in rg-region

$\mathrm{II}_{\mathrm{rg}}(\mathrm{t}) \quad$ weighted fraction of the population infected traveling to $\mathrm{rg}$ region

$I_{\mathrm{rg}}(\mathrm{t}) \quad$ weighted fraction of the population infected traveling from rg-region

\section{Susceptible Movements}

- Increasing the rate of diffusion in the destination locality (rg-region) due to those susceptible people by coming from other regions that may be infected in rg-region, it is calculated as:

$\mathrm{SI}_{\mathrm{ro}, \mathrm{rg}, \mathrm{ss}}(\mathrm{t})=\mathrm{j}_{\mathrm{ro}, \mathrm{rg}, \mathrm{ss}} \times \mathrm{f}_{\mathrm{ro}, \mathrm{rg}, \mathrm{ss}} \times \mathrm{S}_{\mathrm{ro}, \mathrm{ss}}(\mathrm{t})$

The following replace of parameter will be included

$j f_{\text {ro, }, \mathrm{rg}, \mathrm{ss}}=\mathrm{j}_{\mathrm{ro}, \mathrm{rg}, \mathrm{ss}} \times \mathrm{f}_{\mathrm{ro}, \mathrm{rg}, \mathrm{ss}}$

- Decreased diffusion rate in the source region (rg-region) due to the susceptible people by moving to other regions that cannot be infected in rg-region, it is calculated as:

$\mathrm{SE}_{\mathrm{rg}, \mathrm{rd}, \mathrm{ss}}(\mathrm{t})=\mathrm{j} \mathrm{f}_{\mathrm{rg}, \mathrm{rd}, \mathrm{ss}} \times \mathrm{S}_{\mathrm{rd}, \mathrm{ss}}(\mathrm{t})$

The susceptible population living in the rg-region ss-segment must be decremented by the susceptible people belonging to other regions:

$\mathrm{SN}_{\mathrm{rg}, \mathrm{ss}}(\mathrm{t})=\mathrm{S}_{\mathrm{rg}, \mathrm{ss}}(\mathrm{t})-\mathrm{S}_{\mathrm{rd} \in \mathrm{RDE}(\mathrm{rg})} \mathrm{SE}_{\mathrm{rg}, \mathrm{rd}, \mathrm{ss}}(\mathrm{t})$

where

$\mathrm{S}_{\mathrm{rg}, \mathrm{ss}}(\mathrm{t})$ fraction of the susceptible population living in rg-region and ss-segment.

$\mathrm{SI}_{\mathrm{ro}, \mathrm{rg}, \mathrm{ss}}(\mathrm{t})$ fraction of the ss-segment susceptible population traveling from ro-region to rg-region

$\mathrm{SE}_{\mathrm{rg}, \mathrm{rd}, \mathrm{ss}}(\mathrm{t})$ fraction of the ss-segment susceptible population traveling from rg-region to rd-region 
Next table resume the parameters associated with regional modeling:

\begin{tabular}{|c|c|c|c|}
\hline \multicolumn{4}{|c|}{ Table 13. Regional Modeling Parameters - SEIMR/R-S Model } \\
\hline Parameter & Source / Equation & Description & $\begin{array}{c}\text { Measure } \\
\text { Unit }\end{array}$ \\
\hline $\mathrm{j}_{\mathrm{r}, \mathrm{rg}, \mathrm{ss}}$ & Model & $\begin{array}{c}\text { Fraction of ss-segment population } \\
\text { moving from the source region (ro) to } \\
\text { the destination region (rg) }\end{array}$ & fpo/day \\
\hline $\mathrm{f}_{\mathrm{rg}, \mathrm{rd}, \mathrm{ss}}$ & Model & $\begin{array}{c}\text { Fraction time that spends the ss- } \\
\text { segment population of the source region } \\
\text { (ro) into the destination region (rg) }\end{array}$ & hour/day \\
\hline $\mathrm{jf}_{\mathrm{rg}, \mathrm{rd}, \mathrm{ss}}$ & $\mathrm{j}_{\mathrm{rg}, \mathrm{rd}, \mathrm{ss}}{ }^{\prime} \mathrm{f}_{\mathrm{rg}, \mathrm{rd}, \mathrm{ss}}$ & $\mathrm{j}_{\mathrm{rg}, \mathrm{rd}, \mathrm{ss}} \mathrm{f}_{\mathrm{rg}, \mathrm{rd}, \mathrm{ss}}$ & hour/day \\
\hline
\end{tabular}

\subsubsection{Socio Demographic Segment Modeling}

The basic hypothesis is that an infected person in any segment can infect anyone susceptible in any sociodemographic segment.

The calculation process implies that at the level of one region the population of any segment can infect the population of any other segment. To do this, diffusion (infection of susceptible from infected) is managed at a detailed level in the differential equations for all infected states, but in the differential equation the infected transmission is calculated based on the summation of all infected states in all ss-segments.

In traditional aggregated models, this the transfer rate $\square$ (the inverse of contact intensity multiplied by the transmission probability) is assumed fixed for all region and all sociodemographic segments. In SEIMR/R-S the transfer rate depends on the sociodemographic segment in a region and it is called $b_{\mathrm{rg}, \mathrm{ss}}$, this parameter must be calculated by the parameters model.

Then, the contagion of the susceptible population living in the rg-region and belonging to the ss-segment will be the sum of the contagions that occur in the rg-region (people that do not travel out of the rg-region) plus the contagions that occur in the rd destination regions this is

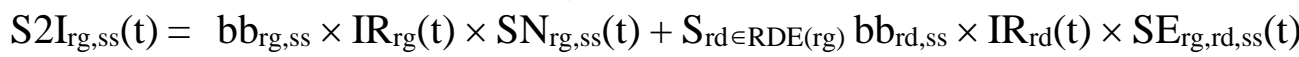

\subsection{General Framework}

The differential equations of the regional-segmented model are:

$$
\begin{aligned}
& \partial S_{\mathrm{rg}, \mathrm{ss}}(\mathrm{t}) / \partial \mathrm{t}=-\mathrm{S} 2 \mathrm{I}_{\mathrm{rg}, \mathrm{ss}}(\mathrm{t})-\mu^{\mathrm{N}} \times \mathrm{S}_{\mathrm{rg}, \mathrm{ss}}(\mathrm{t})+\lambda_{\mathrm{rg}, \mathrm{ss}}^{\mathrm{S}} \times \mathrm{NPX}(\mathrm{t}) \\
& \partial \mathrm{E}_{\mathrm{rg}, \mathrm{ss}}(\mathrm{t}) / \partial \mathrm{t}=\mathrm{S} 2 \mathrm{I}_{\mathrm{rg}, \mathrm{ss}}(\mathrm{t})-\psi \times \mathrm{E}_{\mathrm{rg}, \mathrm{ss}}(\mathrm{t})+\lambda_{\mathrm{rg}, \mathrm{ss}}^{\mathrm{E}} \times \mathrm{NPX}(\mathrm{t}) \\
& \mathrm{st}=\mathrm{I} 0 \\
& \partial \mathrm{I}_{\mathrm{st}, \mathrm{rg}, \mathrm{ss}}(\mathrm{t}) / \partial \mathrm{t}=\psi \times \mathrm{E}_{\mathrm{rg}, \mathrm{ss}}(\mathrm{t})-\delta \alpha_{\mathrm{st}, \mathrm{ss}} \times \mathrm{I}_{\mathrm{st}-1, \mathrm{rg}, \mathrm{ss}}(\mathrm{t})+\lambda_{\mathrm{rg}, \mathrm{ss}}^{\mathrm{I}} \times \mathrm{NPX}(\mathrm{t}) \\
& \mathrm{st} \in \mathrm{I} 1 \mathrm{~F} \\
& \partial \mathrm{I}_{\mathrm{st}, \mathrm{rg}, \mathrm{ss}}(\mathrm{t}) / \partial \mathrm{t}=\delta \zeta_{\mathrm{st}-1, \mathrm{ss}} \times \mathrm{I}_{\mathrm{st}-1, \mathrm{rg}, \mathrm{ss}}(\mathrm{t})-\delta \alpha_{\mathrm{st}, \mathrm{ss}} \times \mathrm{I}_{\mathrm{st}, \mathrm{rg}, \mathrm{ss}}(\mathrm{t}) \\
& \partial \mathrm{R}_{\mathrm{rg}, \mathrm{ss}}(\mathrm{t}) / \partial \mathrm{t}=\Sigma_{\mathrm{st} \in \mathrm{I} 1 \mathrm{~F}} \delta \beta_{\mathrm{st}-1, \mathrm{ss}} \times \mathrm{I}_{\mathrm{st}, \mathrm{rg}, \mathrm{ss}}(\mathrm{t})-\mu^{\mathrm{N}} \times \mathrm{R}_{\mathrm{rg}, \mathrm{ss}}(\mathrm{t})+\Sigma_{\mathrm{ss} \in \mathrm{SSR}(\mathrm{rg})} \lambda^{\mathrm{R}}{ }_{\mathrm{rg}, \mathrm{ss}} \\
& \times \operatorname{NPX}(\mathrm{t}) \\
& \partial \mathrm{D}_{\mathrm{rg}, \mathrm{ss}}(\mathrm{t}) / \partial \mathrm{t}=\Sigma_{\mathrm{st} \in \mathrm{IIF}} \mu \sigma_{\mathrm{ss}} \times \mathrm{I}_{\mathrm{st}, \mathrm{rg}, \mathrm{ss}}(\mathrm{t})
\end{aligned}
$$


$\partial \mathrm{NR}_{\mathrm{rg}}(\mathrm{t}) / \partial \mathrm{t}=\mu^{\mathrm{N}} \times \mathrm{SR}_{\mathrm{rg}, \mathrm{ss}}(\mathrm{t})+\mu^{\mathrm{N}} \times \mathrm{RR}_{\mathrm{rg}}(\mathrm{t})$

where the following rates are defined for the sociodemographic segments

\begin{tabular}{|c|c|c|}
\hline \multicolumn{3}{|c|}{ Table 14. Sociodemographic Biological Parameters } \\
\hline Parameter & Equation & Description \\
\hline $\mathrm{da}_{\mathrm{st}, \mathrm{ss}}$ & $\mathrm{S}_{\mathrm{ag} \in \mathrm{AGS}(\mathrm{ss})} \mathrm{dd}_{\mathrm{ag}, \mathrm{st}}$ & Total exit rate \\
\hline $\mathrm{d}_{\mathrm{st}, \mathrm{ss}}$ & $\mathrm{S}_{\mathrm{ag} \in \mathrm{AGS}(\mathrm{ss})} \mathrm{ds}_{\mathrm{ag}, \mathrm{st}}$ & Worsening exit rate \\
\hline $\mathrm{db}_{\mathrm{st}, \mathrm{ss}}$ & $\mathrm{S}_{\mathrm{ag} \in \mathrm{AGS}(\mathrm{ss})} \mathrm{dg}_{\mathrm{st}, \mathrm{ag}}$ & Recovering exit rate \\
\hline $\mathrm{ms}_{\mathrm{ss}}$ & $\mathrm{S}_{\mathrm{ag} \in \mathrm{AGS}(\mathrm{ss})} \mathrm{m}_{\mathrm{ag}}$ & Mortality rate depending on segment \\
\hline $\mathrm{m}_{\mathrm{ag}}$ & $\mathrm{S}_{\mathrm{st} \in \mathrm{IlF}} \mathrm{ds}_{\mathrm{ag}, \mathrm{st}}$ & Mortality rate depending on age \\
\hline
\end{tabular}

The definition equations of the regional-segmented model are:

$I_{\mathrm{rg}, \mathrm{ss}}(\mathrm{t})=\mathrm{S}_{\mathrm{st} \in \mathrm{INF}} \mathrm{b}_{\mathrm{st}, \mathrm{rg}, \mathrm{ss}}(\mathrm{t}) I_{\mathrm{st}, \mathrm{rg}, \mathrm{ss}}(\mathrm{t})$

$\operatorname{IX}_{\mathrm{rg}}(\mathrm{t})=\mathrm{S}_{\mathrm{ss} \in \operatorname{SSR}(\mathrm{rg})} \operatorname{IS}_{\mathrm{rg}, \mathrm{ss}}(\mathrm{t})$

$\mathrm{II}_{\mathrm{rg}}(\mathrm{t})=\mathrm{S}_{\mathrm{ss} \in \mathrm{SSR}(\mathrm{rg})} \mathrm{S}_{\mathrm{ro} \in \mathrm{ROR}(\mathrm{rg})} \mathrm{j} \mathrm{f}_{\mathrm{ro}, \mathrm{rg}, \mathrm{ss}} \times \mathrm{IS}_{\mathrm{ro}, \mathrm{ss}}(\mathrm{t})$

$I_{\mathrm{rg}}(\mathrm{t})=\mathrm{S}_{\mathrm{ss} \in \mathrm{SSR}(\mathrm{rg})} \mathrm{S}_{\mathrm{rd} \in \mathrm{RDE}(\mathrm{rg})} \mathrm{j}_{\mathrm{rg}, \mathrm{rd}, \mathrm{ss}} \times \mathrm{IS}_{\mathrm{rg}, \mathrm{ss}}(\mathrm{t})$

$I_{\mathrm{rg}}(\mathrm{t})=\mathrm{IX}_{\mathrm{rg}}(\mathrm{t})+\mathrm{II}_{\mathrm{rg}}(\mathrm{t})-\mathrm{IE}_{\mathrm{rg}}(\mathrm{t})$

$\mathrm{SR}_{\mathrm{rg}}(\mathrm{t})=\mathrm{S}_{\mathrm{ss} \in \mathrm{SSR}(\mathrm{rg})} \mathrm{S}_{\mathrm{rg}, \mathrm{ss}}(\mathrm{t})$

$S I_{r o, r g, s s}(t)=j f_{\text {ro,rg,ss }} \times S_{\text {ro,ss }}(t)$

$S E_{\mathrm{rg}, \mathrm{rd}, \mathrm{ss}}(\mathrm{t})=\mathrm{j} \mathrm{f}_{\mathrm{rg}, \mathrm{rd}, \mathrm{ss}} \times \mathrm{S}_{\mathrm{rd}, \mathrm{ss}}(\mathrm{t})$

$\mathrm{SN}_{\mathrm{rg}, \mathrm{ss}}(\mathrm{t})=\mathrm{S}_{\mathrm{rg}, \mathrm{ss}}(\mathrm{t})-\mathrm{S}_{\mathrm{rd} \in \mathrm{RDE}(\mathrm{rg})} \mathrm{SE}_{\mathrm{rg}, \mathrm{rd}, \mathrm{ss}}(\mathrm{t})$

$\operatorname{SIN}_{\mathrm{rg}}(\mathrm{t})=b b_{\mathrm{rg}, \mathrm{ss}}{ }^{\prime} \operatorname{IR}_{\mathrm{rg}}(\mathrm{t}) \times \mathrm{SN}_{\mathrm{rg}, \mathrm{ss}}(\mathrm{t})$

$\operatorname{SIE}_{\mathrm{rg}, \mathrm{ss}}(\mathrm{t})=\mathrm{S}_{\mathrm{rd} \hat{\mathrm{I} R D E}(\mathrm{rg})} b b_{\mathrm{rd}, \mathrm{ss}} \operatorname{IR}_{\mathrm{rd}}(\mathrm{t})^{\prime} \mathrm{SE}_{\mathrm{rg}, \mathrm{rd}, \mathrm{ss}}(\mathrm{t})$

$\mathrm{S} 2 \mathrm{I}_{\mathrm{rg}, \mathrm{ss}}(\mathrm{t})=\operatorname{SIN}_{\mathrm{rg}}(\mathrm{t})+\operatorname{SIE}_{\mathrm{rg}}(\mathrm{t})$

$\mathrm{RR}_{\mathrm{rg}}(\mathrm{t})=\mathrm{S}_{\mathrm{ss} \in \mathrm{SSR}(\mathrm{rg})} \mathrm{R}_{\mathrm{rg}, \mathrm{ss}}(\mathrm{t})$

$\mathrm{DR}_{\mathrm{rg}}(\mathrm{t})=\mathrm{S}_{\mathrm{ss} \in \mathrm{SSR}(\mathrm{rg})} \mathrm{D}_{\mathrm{rg}, \mathrm{ss}}(\mathrm{t})$

From now on, the above mathematical definitions will be summarized as $\left\{\mathrm{S}, \mathrm{E}, \mathrm{I}_{\mathrm{st}}, \mathrm{D}, \mathrm{N}\right\} \in \mathrm{Q}$

The next table shows the equations dividing the increment and the decrement on each state, it must be considered in the implementation of the mathematical models. The table includes the sets that defined the existence of the equations manly for the infected states. 


\begin{tabular}{|c|c|c|c|c|c|}
\hline Set & State & $\begin{array}{c}\text { State } \\
\text { Increment }\end{array}$ & $\begin{array}{c}\text { State } \\
\text { Decrement }\end{array}$ & $\begin{array}{l}\text { Natural } \\
\text { Dead }\end{array}$ & $\begin{array}{l}\text { Exogenous } \\
\text { Increment }\end{array}$ \\
\hline & \multicolumn{5}{|c|}{ REGIONAL - SEGMENT EQUATIONS } \\
\hline SU & $\partial \mathrm{S}_{\mathrm{rg}, \mathrm{ss}}(\mathrm{t}) / \partial \mathrm{t}$ & & $\mathrm{S} 2 \mathrm{I}_{\mathrm{rg}, \mathrm{ss}}(\mathrm{t})$ & $\begin{array}{c}\mu^{\mathrm{N}} \\
\times \mathrm{S}_{\mathrm{rg}, \mathrm{ss}}(\mathrm{t})\end{array}$ & $\begin{aligned} & \lambda_{\mathrm{rg}, \mathrm{ss}}^{\mathrm{S}} \\
& \times \mathrm{NPX}(\mathrm{t})\end{aligned}$ \\
\hline EX & $\partial \mathrm{E}_{\mathrm{rg}, \mathrm{ss}}(\mathrm{t}) / \partial \mathrm{t}$ & $\mathrm{S} 2 \mathrm{I}_{\mathrm{rg}, \mathrm{ss}}(\mathrm{t})$ & $\psi \times \mathrm{E}_{\mathrm{rg}, \mathrm{ss}}(\mathrm{t})$ & & $\begin{aligned} & \lambda_{\mathrm{rg}, \mathrm{ss}}^{\mathrm{E}} \\
\times & \operatorname{NPX}(\mathrm{t})\end{aligned}$ \\
\hline I0 & $\partial \mathrm{I}_{\mathrm{st}, \mathrm{rg}, \mathrm{ss}}(\mathrm{t}) / \partial \mathrm{t}$ & $\psi \times \mathrm{E}_{\mathrm{rg}, \mathrm{ss}}(\mathrm{t})$ & \multirow[t]{2}{*}{$\delta \alpha_{\mathrm{st}, \mathrm{ss}} \times \mathrm{I}_{\mathrm{st}, \mathrm{rg}, \mathrm{ss}}(\mathrm{t})$} & & $\begin{aligned} & \lambda_{\mathrm{rg}, \mathrm{ss}}^{\mathrm{I}} \\
& \times \operatorname{NPX}(\mathrm{t})\end{aligned}$ \\
\hline $\mathrm{I1F}$ & $\partial \mathrm{I}_{\mathrm{st}, \mathrm{rg}, \mathrm{ss}}(\mathrm{t}) / \partial \mathrm{t}$ & $\delta \zeta_{\mathrm{st}-1, \mathrm{ss}} \times \mathrm{I}_{\mathrm{st}-1, \mathrm{rg}, \mathrm{ss}}(\mathrm{t})$ & & & \\
\hline RE & $\partial \mathrm{R}_{\mathrm{rg}, \mathrm{ss}}(\mathrm{t}) / \partial \mathrm{t}$ & $\begin{array}{c}\sum_{\text {st } \in I 1 F} \\
\delta \beta_{\text {st,ss }} \times I_{\text {st, rg, ss }}(t)\end{array}$ & & $\begin{array}{c}\mu^{\mathrm{N}} \\
\times \mathrm{R}_{\mathrm{rg}, \mathrm{ss}}(\mathrm{t})\end{array}$ & $\begin{aligned} & \lambda_{\mathrm{rg}, \mathrm{ss}}^{\mathrm{R}} \\
& \times \operatorname{NPX}(\mathrm{t})\end{aligned}$ \\
\hline ED & $\partial \mathrm{D}_{\mathrm{rg}, \mathrm{ss}}(\mathrm{t}) / \partial \mathrm{t}$ & $\begin{array}{c}\Sigma_{\mathrm{st} \in \mathrm{I} 1 \mathrm{~F}} \\
\mu \sigma_{\mathrm{ss}} \times \mathrm{I}_{\mathrm{st}, \mathrm{rg}, \mathrm{ss}}(\mathrm{t})\end{array}$ & & & \\
\hline ND & $\partial \mathrm{NR}_{\mathrm{rg}}(\mathrm{t}) / \partial \mathrm{t}$ & $\begin{array}{c}\mu^{\mathrm{N}} \times\left(\mathrm{SR}_{\mathrm{rg}}(\mathrm{t})+\right. \\
\left.\mathrm{RR}_{\mathrm{rg}}(\mathrm{t})\right)\end{array}$ & & & \\
\hline & \multicolumn{4}{|c|}{ SUSCEPTIBLE STATE EQUATIONS } & \\
\hline & \multicolumn{4}{|c|}{$\mathrm{SR}_{\mathrm{rg}}(\mathrm{t})=\sum_{\mathrm{ss} \in \mathrm{SSR}(\mathrm{rg})} \mathrm{S}_{\mathrm{rg}, \mathrm{ss}}(\mathrm{t})$} & \\
\hline & \multicolumn{4}{|c|}{$\mathrm{SI}_{\mathrm{ro}, \mathrm{rg}, \mathrm{ss}}(\mathrm{t})=\varphi \phi_{\mathrm{ro}, \mathrm{rg}, \mathrm{ss}} \times \mathrm{S}_{\mathrm{ro}, \mathrm{ss}}(\mathrm{t})$} & \\
\hline & \multicolumn{4}{|c|}{$\mathrm{SE}_{\mathrm{rg}, \mathrm{rd}, \mathrm{ss}}(\mathrm{t})=\varphi \phi_{\mathrm{rg}, \mathrm{rd}, \mathrm{ss}} \times \mathrm{S}_{\mathrm{rd}, \mathrm{ss}}(\mathrm{t})$} & \\
\hline & \multicolumn{4}{|c|}{$\mathrm{SN}_{\mathrm{rg}, \mathrm{ss}}(\mathrm{t})=\mathrm{S}_{\mathrm{rg}, \mathrm{ss}}(\mathrm{t})-\sum_{\mathrm{rd} \in \mathrm{RDE}(\mathrm{rg})} \mathrm{SE}_{\mathrm{rg}, \mathrm{rd}, \mathrm{ss}}(\mathrm{t})$} & \\
\hline & \multicolumn{4}{|c|}{$\operatorname{SIN}_{\mathrm{rg}, \mathrm{ss}}(\mathrm{t})=\beta \beta_{\mathrm{rg}, \mathrm{ss}} \times \operatorname{IR}_{\mathrm{rg}}(\mathrm{t}) \times \mathrm{SN}_{\mathrm{rg}, \mathrm{ss}}(\mathrm{t})$} & \\
\hline & \multicolumn{4}{|c|}{$\operatorname{SIE}_{\mathrm{rg}, \mathrm{ss}}(\mathrm{t})=\sum_{\mathrm{rd} \in \mathrm{RDE}(\mathrm{rg})} \beta \beta_{\mathrm{rd}, \mathrm{ss}} \operatorname{IR}_{\mathrm{rd}}(\mathrm{t}) \times \mathrm{SE}_{\mathrm{rg}, \mathrm{rd}, \mathrm{ss}}(\mathrm{t})$} & \\
\hline & \multicolumn{4}{|c|}{$\mathrm{S} 2 \mathrm{I}_{\mathrm{rg}, \mathrm{ss}}(\mathrm{t})=\operatorname{SIN}_{\mathrm{rg}}(\mathrm{t})+\operatorname{SIE}_{\mathrm{rg}}(\mathrm{t})$} & \\
\hline & \multicolumn{4}{|c|}{ INFECTED STATE EQUATIONS } & \\
\hline & \multicolumn{4}{|c|}{$\mathrm{IS}_{\mathrm{rg}, \mathrm{ss}}(\mathrm{t})=\sum_{\mathrm{st} \in \mathrm{INF}} \beta_{\mathrm{st}, \mathrm{rg}, \mathrm{ss}}(\mathrm{t}) \mathrm{I}_{\mathrm{st}, \mathrm{rg}, \mathrm{ss}}(\mathrm{t})$} & \\
\hline & \multicolumn{4}{|c|}{$\mathrm{IX}_{\mathrm{rg}}(\mathrm{t})=\sum_{\mathrm{ss} \in \mathrm{SSR}(\mathrm{rg})} \mathrm{IS}_{\mathrm{rg}, \mathrm{ss}}(\mathrm{t})$} & \\
\hline & \multicolumn{4}{|c|}{$\mathrm{II}_{\mathrm{rg}}(\mathrm{t})=\sum_{\mathrm{ss} \in \mathrm{SSR}(\mathrm{rg})} \sum_{\mathrm{ro} \in \mathrm{ROR}(\mathrm{rg})} \varphi \phi_{\mathrm{ro}, \mathrm{rg}, \mathrm{ss}} \times \mathrm{IS}_{\mathrm{ro}, \mathrm{ss}}(\mathrm{t})$} & \\
\hline & \multicolumn{4}{|c|}{$\mathrm{IE}_{\mathrm{rg}}(\mathrm{t})=\sum_{\mathrm{ss} \in \mathrm{SSR}(\mathrm{rg})} \sum_{\mathrm{rd} \in \mathrm{RDE}(\mathrm{rg})} \varphi \phi_{\mathrm{rg}, \mathrm{rd}, \mathrm{ss}} \times \mathrm{IS}_{\mathrm{rg}, \mathrm{ss}}(\mathrm{t})$} & \\
\hline & \multicolumn{4}{|c|}{ OTHER EQUATIONS } & \\
\hline & \multicolumn{4}{|c|}{$\mathrm{RR}_{\mathrm{rg}}(\mathrm{t})=\sum_{\mathrm{ss} \in \mathrm{SSR}(\mathrm{rg})} \mathrm{R}_{\mathrm{rg}, \mathrm{ss}}(\mathrm{t})$} & \\
\hline
\end{tabular}




\section{Implementation}

The model was implemented by the Technological Institute of Mexico, specifically by the ITCM (Instituto Tecnológico de Ciudad Madero) and was applied to three municipalities of the south of the State of Tamaulipas in Mexico which are: Tampico, Ciudad Madero and Altamira, which also make up a conurbated metropolitan area.

Figure 10. Tampico, Ciudad Madero and Altamira Metropolitan Area (TMA)

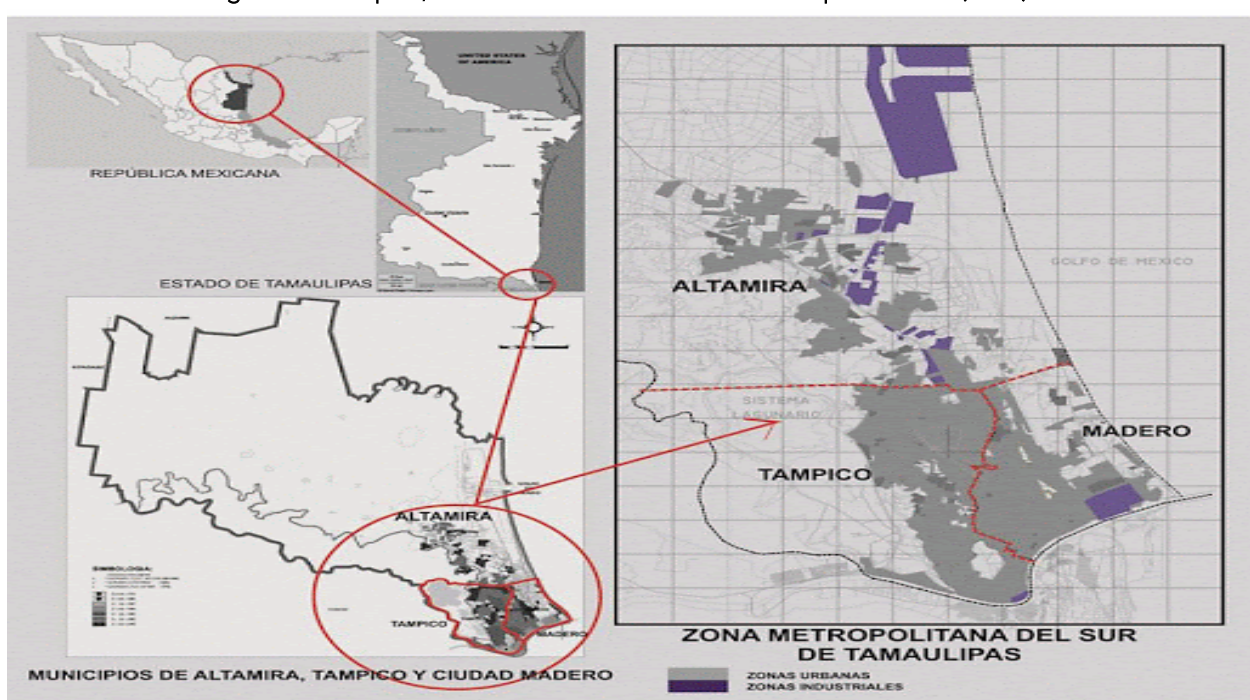

The population of the TMA metropolitan area is presented in the following table:

\begin{tabular}{|c|c|c|c|}
\hline \multicolumn{4}{|c|}{ Table 16. Metropolitan Area Tampico, Ciudad Madero and Altamira } \\
\hline Region & ID & $\begin{array}{c}\text { Population } \\
\text { (inhabitants) }\end{array}$ & Type \\
\hline Tampico & TAM & 327308 & Downtown \\
\hline Madero & MAD & 216664 & Tourist \\
\hline Altamira & ALT & 246549 & Industrial \\
\hline Metropolitan Area & TMA & 790521 & \\
\hline
\end{tabular}

For sociodemographic segments:

- Eighteen age groups were established as shown in next table including the distribution in TMA and the epidemic mortality.

\begin{tabular}{|c|c|c|c|c|c|}
\hline \multicolumn{5}{|c|}{ Table 17. Population by Age Group } & Region \\
\hline ID & \multirow{2}{*}{ Group } & \multicolumn{3}{|c|}{ Romic } \\
\cline { 3 - 5 } & & Altamira & Madero & Tampico & Mortality \\
\hline Y00 & 0 a 4 años & 22436 & 14299 & 20948 & 0.008600 \\
\hline Y05 & 5 a 9 años & 24408 & 16467 & 22584 & 0.0003000 \\
\hline Y10 & 10 a 14 años & 23916 & 18200 & 24221 & 0.0003000 \\
\hline Y15 & 15 a 19 años & 21697 & 17117 & 26839 & 0.0007000 \\
\hline Y20 & 20 a 24 años & 20956 & 17983 & 27167 & 0.0011840 \\
\hline
\end{tabular}




\begin{tabular}{|c|c|c|c|c|c|}
\hline Y25 & 25 a 29 años & 18737 & 15600 & 23238 & 0.0015392 \\
\hline Y30 & 30 a 34 años & 19724 & 14299 & 22911 & 0.0018944 \\
\hline Y35 & 35 a 39 años & 19724 & 15600 & 22584 & 0.0024864 \\
\hline Y40 & 40 a 44 años & 17998 & 16033 & 25203 & 0.0033152 \\
\hline Y45 & 45 a 49 años & 15533 & 13867 & 22911 & 0.0066666 \\
\hline Y50 & 50 a 54 años & 13560 & 15600 & 22257 & 0.0097560 \\
\hline Y55 & 55 a 59 años & 9615 & 11917 & 17674 & 0.0144714 \\
\hline Y60 & 60 a 64 años & 6904 & 8881 & 16039 & 0.0217884 \\
\hline Y65 & 65 a 69 años & 4191 & 7584 & 11457 & 0.0258020 \\
\hline Y70 & 70 a 74 años & 2958 & 4984 & 8183 & 0.0377720 \\
\hline Y75 & 75 a 79 años & 1973 & 3683 & 5891 & 0.0578550 \\
\hline Y80 & 80 a 84 años & 1233 & 2384 & 4255 & 0.0843220 \\
\hline Y85 & 85 años y más & 986 & 2166 & 2946 & 0.1795500 \\
\hline
\end{tabular}

- Two socio-economic strata were considered: poor and non-poor shows the number of inhabitants of each stratum per city.

\begin{tabular}{|c|c|c|c|}
\hline \multicolumn{2}{|c|}{ Table 18. Socio-Economic Strata Population - Distribution by Region } \\
\hline $\begin{array}{c}\text { Socio-Economic } \\
\text { Strata }\end{array}$ & Altamira & Madero & Tampico \\
\hline poor & 129,438 & 81,249 & 125,359 \\
\hline non-poor & 117,111 & 135,415 & 201,949 \\
\hline
\end{tabular}

For verification purposes of the simulation model, March 24/2020 is considered as the beginning of the COVID-19 epidemic in TMA; the following table presents the initial conditions for that day (inhabitants by epidemiological state).

\begin{tabular}{|c|c|c|c|c|c|c|c|c|c|}
\hline \multicolumn{10}{|c|}{ Table 19. Epidemic Initial Conditions in TMA } \\
\hline Region & SU & EX & I0 & I1 & I2 & I3 & ED & ND & RE \\
\hline Tampico & 327307 & 0 & 0 & 0 & 1 & 0 & 0 & 0 & 0 \\
\hline Madero & 216662 & 0 & 0 & 0 & 2 & 0 & 0 & 0 & 0 \\
\hline Altamira & 246548 & 0 & 0 & 0 & 1 & 0 & 0 & 0 & 0 \\
\hline
\end{tabular}

The detailed configuration of parameters, the result and the analysis of those of the experiments is reported in the working paper "SEIMR/R-S. General Epidemic Simulation Model Multi-Infected States - Multi SocioDemographics Segments - Multi-Region Mobility. Validation Case: Metropolitan Area: Tampico, Ciudad Madero and Altamira" avalaible in http://www.doanalytics.net/Documents/DW-2B-ITCM-SEIMR-R-SEpidemic-Model-Case-TMA.pdf. 
The following graphs are examples extracted from that document.

- Impact sociodemographic segments (without mobility):

Figure 11. Example: Aggregate Results for Metropolitan Area (TMA) - Sociodemographic Segments
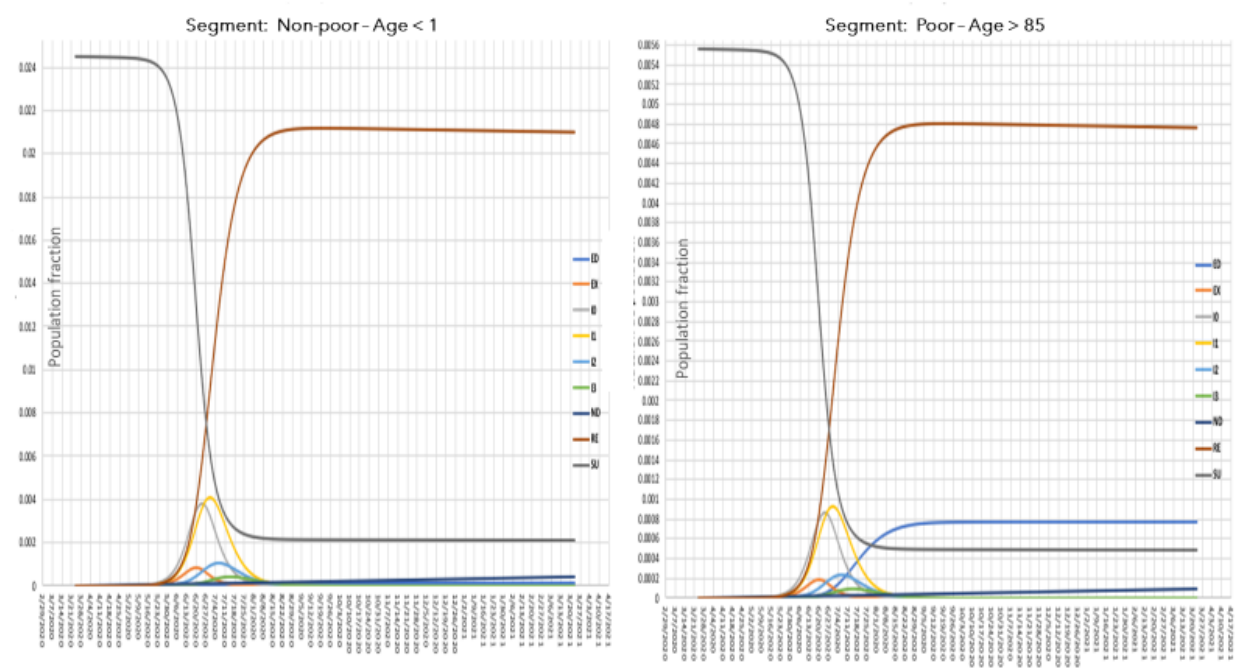

- Impact Mobility between regions:

Figure 12. Example: Aggregate Results for Metropolitan Area (TMA) - Mobility

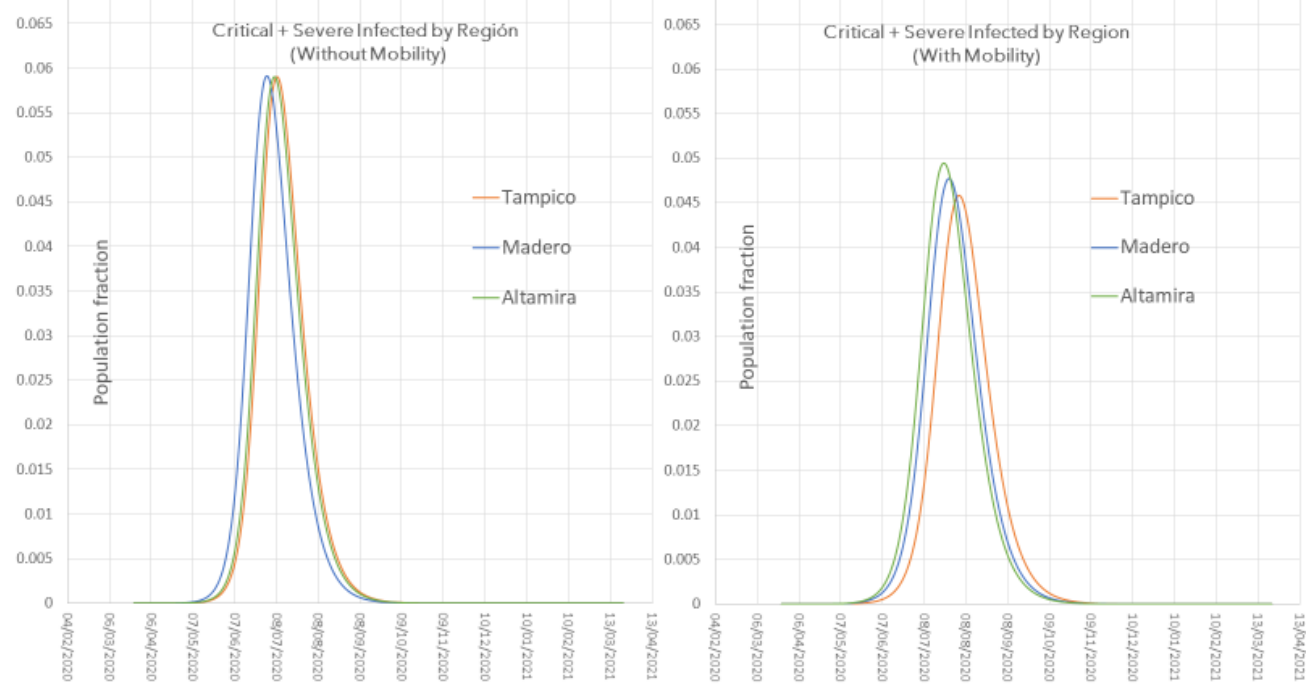


The simulation model was implemented in Java JRE 8 language.

Figure 13.SEIMR/R-S Screenshot

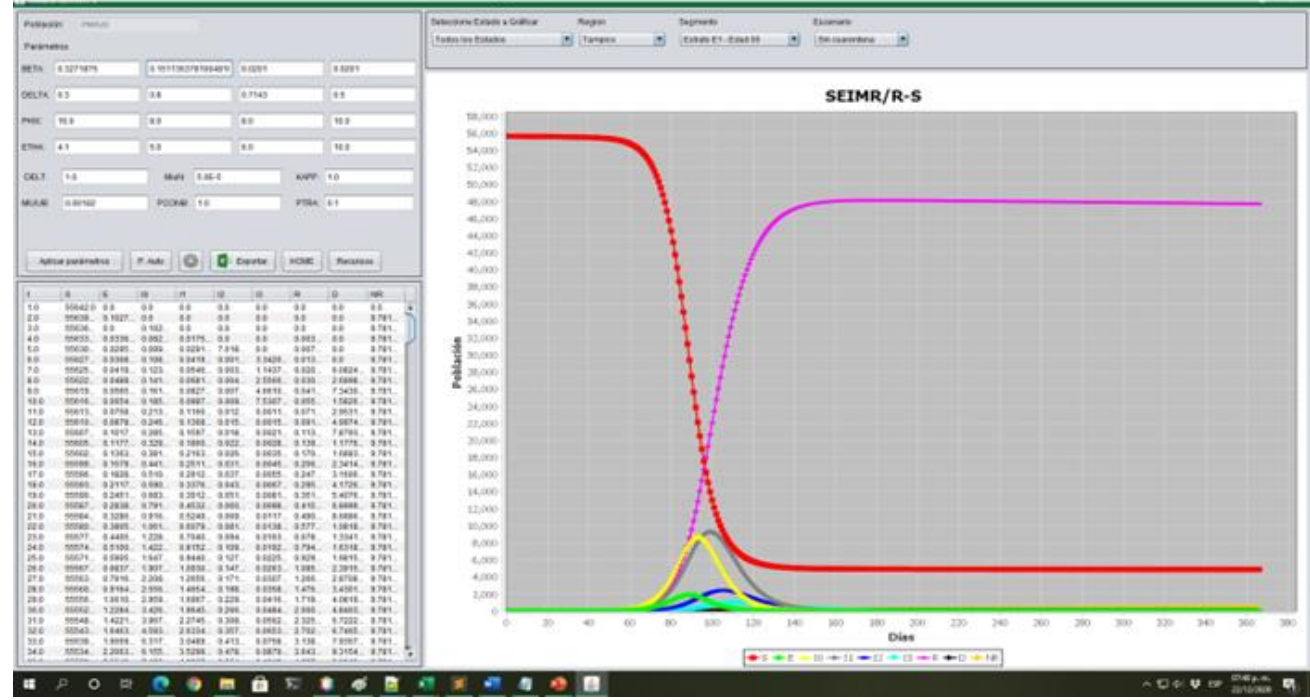

SEIMR/R-S simulation model is available under GNU license. The instructions for download the source code are in http://www.doanalytics.net/Documents/SEIMR-R-S-GNU-license.pdf

\section{Acknowledgement}

The author explicitly acknowledges the support made in the implementation of the computational models and in the discussion of the formulation to the researchers (of the ITCM) Laura Cruz and Alfredo Brambila their dedication to the SEIMR/R-S project for the TMA case.

Comments and suggestions received from professors Renato Leone (U. of Camerino) and Stefan Pickl (Universität der Bundeswehr München) are also appreciated.

\section{Funding}

This project has been funding by DecisionWare. CONACYT (Consejo Nacional de Ciencia y Tecnología de México) vía provides personal and funds for the implementation of the JAVA program.

\section{References:}

1. Cai, Y., Kang, Y., Banerjee, M., \& Wang, W. (2015). A stochastic SIRS epidemic model with infectious force under intervention strategies. Journal of Differential Equations, 259(12), 7463-7502.

2. Hethcote, H. W. (2000). "The Mathematics of Infectious Diseases." SIAM Review 42.4 (2000), pp. 599-653. 
http://www.doanalytics.net/Documents/SEIMR-R-S-OPT-OPTEXImplementation.pdf

3. Huang G. (2016). Artificial infectious disease optimization: A SEIQR epidemic dynamic model-based function optimization algorithm. Swarm and evolutionary computation, 27, 31-67.

https://doi.org/10.1016/j.swevo.2015.09.007

4. Jing, W., Jin, Z., \& Zhang, J. (2018). An SIR pairwise epidemic model with infection age and demography. Journal of biological dynamics, 12(1), 486-508.

5. Kermack, W.O. and Mc Kendrick, A. G.,(1927) "Contributions to the Mathematical Theory of Epidemics, Part I”. Proc. R. Soc. London, Ser. A, 115, 1927, 700-721.

6. Mejía Becerra, J. D. et. al. (2020). "Modelación Matemática de la Propagación del SARS-CoV-2 en la Ciudad de Bogotá. Informal Circulation Document.

7. Velásquez-Bermúdez (2021b), J. et al. , "SEIMR/R-S General Epidemic Model. Theory, Validation and Applications". Working Paper.

http://www.doanalytics.net/Documents/DW-ITM-SEIMR-R-SEpidemic-Model.pdf

8. Velásquez-Bermudez, (2019). "OPTEX Mathematical Modeling System".

http://www.doanalytics.net/Documents/OPTEX-MathematicalModeling-System-Descriptive.pdf

9. Velásquez-Bermudez, (2020). "PART IV: SEIMR/R-S/OPT. Epidemic Management Optimization Model Parameters Model for Bogotá City". Working Paper. OPTEX-Mathematical-ModelingSystem-Descriptive http://www.doanalytics.net/Documents/ DW-4BOPCHAIN-Health-Epidemic-Parameters-Model-Case-Bogota.pdf

10. Velasquez-Bermudez, J. (2021d), Artificial Hypothalamus: Artificial Intelligence and Mathematical Programming Integration (January 17, 2021). Available at SSRN: https://ssrn.com/abstract $=3767763$

11. Velasquez-Bermudez, J. (2021e), "SEIMR/R-S/OPT. OPTEX Expert System Implementation“.

12. Velásquez-Bermúdez, J., Leone, R. and Pickl, S. (2021) "Public Health and High-Precision Decision-Making". German Journal of Operations Research (DAS MAGAZIN DER GOR NR.71 / APRIL 2021 / ISSN 1437-2045)

13. Velásquez-Bermudez, J., (2021a) SEIMR/R-S. General Epidemic Simulation Model: Multi-Infected States - Multi Sociodemographic Segments - Multi-Region Mobility. Theory (April 23, 2021). Available at SSRN: http://ssrn.com/abstract=3832799 
14. Velásquez-Bermudez, J., (2021b) SEIMR/R-S/OPT. Epidemic Management Optimization Model Control Policies, Vital Health Resources and Vaccination. Theory Submitted to European Scientific Journal, Special Edition Public Policies in Times of Pandemics in the discipline Health Policies. Available at

15. Velásquez-Bermúdez, J., (2021c) Epidemic State and Parameter Estimation using a Dual Multi-State Kalman Filter". http://www.doanalytics.net/Documents/DW-6-OPCHAIN-HealthDual-Multi-State-Kalman-Filter-Stimation-Epidemic-Parameters.pdf 16. Velásquez-Bermúdez, J., Cruz, L., Brambila, A., Fraire, H., RangelValdez, N. and Gomez, C. (2021). PART II - ANNEX B. SEIMR/R-S General Epidemic Simulation Model. Validation Cases: Colombia: Bogotá, Mexico: Tampico, Ciudad Madero y Altamira. (Available at: http://www.doanalytics.net/Documents/DW-2B-ITCM-SEIMR-R-SEpidemic-Model-Case-TMA.pdf) 